\title{
Domskolen i Slesvig mellem Krigene
}

\author{
(1848-64) \\ Af Kjeld Galster. \\ Under Oprøret
}

Naar Rektoren ved Domskolen i Slesvig, J. P. A. Jungclaussen (f. 1788), tænkte tilbage paa de første Tiaar af Aarhundredet, fastslog han: „Alle Lehrer erfüllte das beglückende Gefühl unter dem Schutz der höchsten Humanität zu stehen“, og den kongetro Holstener tilføjer bittert: „Ein solches Glück werden besonders solche Schulmänner zu schätzen wissen, welche in weniger freundlichen Verhältnissen der Art gelebt haben mögen." ${ }^{\text {"1) }}$

Maaske har man haft noget imod ham, straks da han 1837 tiltraadte Rektoratet (fra 1814 havde han været Rektor i Glückstadt); i hvert Fald sank Elevtallet samme Aar fra 70 til 44. Men under alle Omstændigheder fik han en stor Del af Borgerskabet imod sig ved sin Stilling til Spørgsmaalet: Realskole.

Overalt i Monarkiet var der Bestræbelser fremme for at faa oprettet Skoler for Handelsstandens og Haandværkernes Børn med „reale Fag“; Latinskolen vạr for Emıbedsstanden, sagde man. Jungclaussen mente, at Latinskolen selv kunde oprette slige Klasser, men Bevægelsen var for stærk, netop ved Paasketid 1848 blev der tegnet 5-600 Rt. Kurant aarlig i 5 Aar og Realskolen oprettet, hvorved Domskolen mistede mange Elever.

Naar Kealskolen havde slig Succes, var det ogsaa, fordi dens Idé knyttedes sammen med den oprørske Bevægelse, „die Anstalt wird als eine aus dem Volkswillen hervorgegangenen Errungenschaft angesehen", mente Rektor. ${ }^{2}$ )

1) Einladungsschrift 1852. S. 9. Hvor intet udtrykkeligt siges, er Skolens Programmer 1838-63 i det følgende Kilderne

2) Slesvigske Ministeriums Forestillingsprotokol. 27/7 1852. 
I det hele blev Stemningen - ogsaa paa Skolen - mere og mere bitter og paagaaende. „Det politiske Had“, skrev Jungclaussen, ${ }^{3}$ ) „kan ingen loyal Embedsmand undgaa.. For at kunne vurdere Misligheden ved en slig Stilling behøver man kun at vide, at af et Lærerkollegium paa 8 Lærere var de 6 afgjorte, tildels fanatiske Slesvigholstenere; hver Lejlighed var dem velkommen til at overdænge den anderledes tænkende med Spot, Haan, ja Foragt; det kan være, at der ogsaa blev indvirket paa Eleverne. Naar ogsaa hele Publikum er besat af politisk Had, saa kan det vel være tilgiveligt, om en Lærer i en saadan Situation bliver overvældet af Mismod."

Da Oprøret udbrød, og Domkirkens Klokker Kl. 10 om Formiddagen d. 24. Marts rungede, lød disse Stormklokker for Skolens Rektor som Domskolens Gravklokker.

Elevtallet gik i Lobet af et halvt Aar ned fra 135 til 98. Dette skyldtes naturligvis delvis, at udenbys Forældre under disse Forhold tog deres Børn hjem. Men ogsaa at de større Skoleelever greb til Vaaben. Af øverste Klasse blev kun 5 tilbage, 11 „folgten dem Rufe der Waffen“, desuden 5 Sekundanere og 1 Obertertianer.

I de følgende $1^{1 / 2}$ Aar til Paasken 1850 sank Frekvensen yderligere, helt ned til 69 .

Alle Lærerne var der stadigvæk, men det var altsaa smaa Klasser de havde, 11-12 i Gennemsnit.

Vi kan følge en loyal, tysk Lærer (Grünfeld) i hans Forsvar for at blive:4) Ved Oprørets Begyndelse blev der af den provisoriske Regering ikke forlangt nogen Anerkendelse, og under saadanne Omstændigheder troede han, at han, bøjende sig for den faktiske Magt, maatte forblive i sit Embede, saaæænge der ikke blev forlangt nogen Handling af ham, der stred mod hans Embedsed. „Ich hielt dieses für meine Pflicht, da es für das wahre Interesse des Landes und für die gerechte Sache

\footnotetext{
3) Til sl. Min. 14/9 1851. De lærde Skoler 1848-51. 3 Dpt. St. A. No, $\$ 02$ (Rigsarkivet).

4) Grünfeld til Jungclaussen. 23/9 1850. (Smst.).
} 
nur als wünschenwert erscheinen musste, dass neben den Pflichtvergessenen möglicht viele loyale Beamte dem Lande erhalten würden".

D. 18/5 1850 sendte Jungclaussen Skolens Timeplaner for 1849 og 50 til Regeringskommissionen i Flensborg (Landesverwaltung für das $\mathrm{Hz}$. Schleswig: $\left.{ }^{5}\right)$ Han har ikke turdet gøre det for, siger han, enhver saadan Pligtopfyldelse vilde blive regnet for Landsforræderi. I Byen og over hele Landet er han desuden bekendt som mislibig, fordi han har haft den Dristighed at være mellem de faa, der ikke kunde forene det med deres Samvittighed at underskrive Embedsmændenes Adresse mod Anerkendelsen af den af Kongen oprettede Regering. Det indbringer ham daglig de bitreste Krænkelser. Man lurer paa Lejlighed til hans Afsættelse.

Hvis han havde meddelt Lærerne, at han vilde sende Timeplanerne til Flensborg, vilde Flertallet utvivlsomt have nægtet ham enhver Lydighed.

Brevhemmeligheden har han ingen Tillid til, og han har kun kunnet beslutte sig til disse aabne Tilstaaelser, fordi Adjunkt Grünfeld kan tage denne Skrivelse med til Flensborg.

\section{Reorganisation}

Saa kom Sejren ved Isted, et dræbende Slag ogsaa for den slesvig-holstenske Aand i Domskolen.

Kanontordenen var næppe døet hen, før Lærerne, sammen med Byens øvrige Embedsmænd, var flygtet mod Syd, og ingen af dem kom tilbage.

Den eneste, der blev — foruden Rektor og Grünfeld — var Konrektor Dr. A. J. F. Henrichsen.

Hos Eleverne gjorde den samme Bevægelse sig gældende, alle Primanerne (8) forlod Skolen, og Klassen stod tom indtil Paasken 1851. Ialt sank Elevtallet til 27 i hele Skolen, kun 20 pCt. af Frekvensen i 1847.

s) Smst. 
Disse 27 var fordelt paa 5 Klasser (med 4-7 i hver). Til at bestride Undervisningen var der altsaa kun 3 Lærere, der jo saa maatte overtage alle Fagene. Klasserne blev undervist sammen to og to (Sekunda alene). Vanskelighederne forøgedes ved, at Skolen i den første Tid blev brugt til Lazaret.

Saa snart Ministeriet for Slesvig var oprettet, søgte man at faa Domskolen reorganiseret.

For at støtte Domskolen i Konkurrencen med den private Realskole blev der 1852 oprettet en Forberedelsesklasse.

Latinskolen i Husum blev nedlagt, saa Domskolens Opland blev saa meget større.

Som bekendt blev Haderslev lærde Skole gjort helt dansk og Flensborg fik dansk og tysk Undervisningssprog, medens det $\mathbf{i}$ Slesvig blev ved at være udelukkende tysk.

Men som det vil ses af det følgende, var der alligevel et maalbevidst Arbejde i dansk Retning:

September 1851 ansattes 4 nye Lærere, deraf var de 3 Danske og een Holstener.

Der var nok tidligere blevet undervist i Dansk, men Sproget havde haft en Plads som Askepot, kun 5 Timer $\mathbf{i}$ alt $\mathbf{i}$ hele Skolen, der var lagt i Hænderne paa to Holstenere fra Altona og Neumünster.

$\mathrm{Nu}$ blev det anderledes. Timetallet forøgedes fra 5 til 14, 7 pCt. af det samlede Timetal (ligesom Tysk), i Kongeriget var det 9 pCt.; og disse 2-3 Timer i hver Klasse kunde de dygtige danske Lærere nok faa noget ud af.

Maalet for Regenburg og det slesvigske Ministerium var, at de Studenter, der kom fra Slesvig By, efterhaanden skulde være saa dygtige i Dansk, at de, om de ønskede det, kunde studere i København uden sproglige Vanskeligheder.

For at understøtte disse Bestræbelser bevilgedes der (17/10 1851) $1000 \mathrm{Rd}$. til Indkøb af danske Bøger (og fysiske Apparater), og Aaret efter var der et fyldigt Udvalg af vore betydeligste Digtere i Domskolens Bibliotek. 
Skoleaaret havde i Slesvig hidtil været delt i to Semestre, der afsluttedes ved Paaske og Mikkelsdag.

$\mathrm{Nu}$ foresloges det, at Eksamen skulde falde i Juli, og at Skoleaaret skulde gaa fra 23/8 til 23/7 som i Kongeriget. Rektor og 3 tyske Lærere stemte imod af Hensyn til de holstenske Skoler og til Universitetet i Kiel.Men Ministeriet indstillede det alligevel til Kongen (15/9 1952): $)$ "Under Insurrektionen er saavel ved Flensborg som ved Slesvig Skole saa godt som alle de i øverste Klasse og nogle af de i næstøverste Klasse værende Elever frivillig traadt ind $i$ den insurrektionelle Armé og have baaret Vaaben mod Deres Majestæt. Paa Grund heraf er der f. T. kun meget faa Elever i de øverste Klasser, og af disse er der, navnlig i Slesvig, næppe nogen, der kunde dimitteres $i$ indeværende Aar". Saaledes kom Dimissionstiden til at stemme med Københavns og være i Strid med Kiels Universitet, hvad vel ogsaa var tilsigtet.

\section{Strid mellem den tyske Ledelse og de danske Lærere,}

Som man ser, søgte Rektor Jungclaussen og Konrektor Henrichsen at forhindre, at Skoleaaret blev lagt om, som man onskede det fra dansk Side.

Det var ikke det eneste Punkt; snart var der en bitter Strid mellem den tyske Ledelse af Skolen og de danske Lærere.

I Slutningen af 1853 var den unge Emil Manicus blevet forflyttet fra Haderslev til Slesvig, og gennem ham fik den danske Opposition Mæle.

1. Marts 1854 skrev han til Regenburg $)$ : „Kampen mellem os danske Lærere og den tyske Majoritet er naturligvis ikke aabenlys, og ingen af os Danske hindres ligefrem i sin Virksomhed, tværtimod bevares det ydre kollegiale Forhold, men at vore Tanker, Intentioner og Bestræbelser alligevel gaa $i$ aldeles modsat Retning er bleven mig efter et Fjerdingaars Skoleliv

6) Forestillingsprotokollen 15/9 1852.

7) De Regenburgske Papirer i Rigsarkivet. 
her aldeles klart. Der er overhovedet næsten ingen Sympathi eller Tilknytningspunkter mellem os, da baade Anskuelser og Følelser gaa til forskellige Sider. Ikke mener jeg, at baade Rektor og Konrektor i deres hele Adfærd ej skulde vise sig som loyale Mænd, tværtimod gøre de Alt for at hævde Loyalitetens Standpunkt; men de ere nu engang aldeles tyske Skolemænd, der ikke kende det mindste til Danmark og Danskhed og kun leve $\mathrm{i}$ høje Tanker om den tyske Dannelses uendelige Fortræffelighed, og naturligvis, saavidt det staar i deres Magt, føre Disciplene samme Vej. Konrektor er tilvisse en meget praktisk Skolemand og holder især over sin udelukkende Indflydelse i Prima som Klasselærer; her faar Disciplene det afgørende Præg, og alle deres Tankers ubevidste Tyngdepunkt bliver Tyskland. Til denne tyske Retning regner jeg en vis pathetisk, ordgydende Dannelse, hvorved det ofte skorter paa solide, reelle Kundskaber, en aldeles ubehørig Overvægt af de klassiske Fag over Real-Videnskaberne, hvori vor Secunda og Prima ere meget svage, æsthetisk Interpretation af Goethe og Shakespeare, og flere saadanne højtstilede Ting, hvori Konrektoren har sin Force, ligesom mange tyske Skolemænd, og som give Disciplene en fejlagtig Forestilling om deres Dannelses Standpunkt. Den tyske Ungdom er desværre meget modtagelig for denne Retning, og som Følge heraf, ligesom ogsaa ved sit praktiske Talent, udviser Konrektor en stor Indflydelse navnlig over Prima, hvor Disciplene ret egentlig forberedes til Universitetet og ere $\mathrm{i}$ den mest modtagelige Alder. Endvidere har Konrektor ogsaa al historisk Undervisning i Prima, hvorved hans Stilling bliver endnu vigtigere. Under disse Omstændigheder gaa naturligvis en stor Del af vore Bestræbelser, at give Disciplene en dansk Aand, baade i national og videnskabelig Henseeende, tabt.

Saavidt jeg kan skønne, vil Undervisningen næppe bære gode Frugter i dansk Retning, medmindre der sker en Forandring af gennemgribende Natur. Den indre Modsætning i Lærernes Bestræbelser har noget Fortærende, og det er meget 
vanskeligt at forebygge eller undgaa, at denne Dissonans ikke udtaler sig og fjerner os fra hinanden. Skolens Flid og Disciplin er ellers særleles god, og Lærernes Forhold til Disciplene, saavidt jeg kan dømme, smukt og godt.

Dette skal ikke være nogen Klage mod nogen af vore tyske Kolleger personlig, men det synes os, at det danske Element her ved denne vigtige Anstalt er noget stedt i Betryk og Fare, og at gode Frugter ikke kunne sikres for Fædrelandet, hvis det danske Element ikke bliver saa stærkt, at det sejrer og behersker det tyske."

Et Par Dage efter at dette Brev var skrevet, tørnede de to Partier sammen.

En af de danske Lærere, Preysz, havde i længere Tid været syg, og hans Timer havde været fordelt mellem Kollegerne.

$\mathrm{Nu}$ ønskede Rektoren imidlertid en Vikar og foreslog $\mathrm{Pa}-$ stor Simonsen eller Pastor Sørensen. Danskerne talte derimod: begges politiske Sindelag og Antecedentier var betænkelige, de var kompromitterede. Konrektoren hævdede, at der ingen politiske Betænkeligheder kunde være, der var jo givet Amnesti, og Rektoren mente, at politiske Sym- eller Antipatier ikke maatte gøre sig gældende i Skolesager.

3. Marts fik Lærerne at vide, at Rektoren, i Henhold til Regeringens Fuldmagt, havde antaget Pastor Sørensen. De gik til Rektoren. Forgæves, han havde Ansvaret, Sagen kunde paa ingen Maade lade sig arrangere anderledes.

4. Marts protesterede de atter, men igen forgæves.

5. Marts skrev de saa alle 3 (Manicus, H. Lorenzen og Blichert) til Regenburg: „Hvad nu Hr. Sørensens Vakancevirksomhed angaar, saa er det ikke saa meget denne selv, vi frygte, som Sagens Følger for os Danske hernede. Det er bleven vist os ved denne Lejlighed, at Skolens Ledelse er aldeles i tyske Hænder, og at der gaas frem med planmæssig Taktik for at faa vor Indflydelse paa Skolens Anliggender ophævet. Og dette vil for den store tyske Majoritet nu være saare let. Navnlig er Konrektoren den, som mere og mere viser sig i sin sande 
Skikkelse og leder og samler de tyske Kræfter mod os Danske. Dette giver naturligvis en dels hemmelig, dels aaben fortærende Kamp, og det er smerteligt følt af os Danske, at vi maa bukke for Tyskerne. Vor Indflydelse paa Konferencen vil fremdeles være lig Nul, og at dette ogsaa med Tiden vil svække vor Indflydelse paa Disciplene og overhovedet umuliggøre en gavnlig Virksomhed for os i alle Retninger, er aldeles klart.

$\mathrm{Vi}$ danske Kollegaer have meget og længe talt om vor Stilling og Skolens Fremtid hernede; der er fuldkommen Enighed hos os derom, at vor Stilling for Fremtiden ikke er til at holde, medmindre vi ville give os Rektor og Konrektor i Vold og lade Tingene gaa, som de bedst kunne, hvilket dog ingen af os kan forene med sin Overbevisning og Pligtfølelse. Vi ere efterhaanden komne til den Erkendelse, at hele Spørgsmaalet angaaende Domskolens Fremtid drejer sig om dette Alternativ: enten ville de danske Lærere oprives i en frugtesløs Kamp, og til Slutningen den tyske Aandsretning fuldkommen sejre eller, skal dette ikke ske, saa maa Konrektor paa en eller anden Maade fjernes.

Vel er det haardt at skulle udtale en saadan Dom om en af vore Kollegaer, men Forholdene og et Blik paa Skolens Fremtid byder det. Med de nuværende Lærerkræfter vilde, efter vort Skøn, ved hans Fjernelse Skolens Gang temporairt ikke lide Afbræk. Dette maa vi anse for Hovedpunktet; enhver anden Forholdsregel turde kun alt for let vise sig illusorisk.

Det gør os ondt, Hr. Etatsraad, at De ikke faar glædeligere Efterretninger fra Domskolen, men Forholdene have desværre udviklet sig saaledes og kunde vel næppe andet.“

Ministeriet for Slesvig handlede hurtigt. Omgaaende blev der sendt en Skrivelse til Rektor Junclausen, at Pastor S $ø-$ rensens Vikariat straks skulde ophøre, og Rektor maatte ved Cirkularskrivelse meddele Lærerne, at den gamle Timeplan atter skulde træde i Kraft - til ligesaa stor Glæde for det ene Parti som til Sorg for det andet.

Ogsaa andet skete, der kunde gøre Rektor ked af Stillingen: 
Et Par Maaneder senere (i Juni 1854) skulde der være Fugleskydning. De danske Lærere sagde straks, at Eleverne nødvendigvis maatte gaa under Danebrog. Det behøvedes ikke, mente Rektoren, Ungdommen kunde godt bære Fantasiflag, man havde aldrig i Sydslesvig brugt Danebrog ved slige Lejligheder; han vilde nok $\mathrm{i}$ Venlighed anmode Drengene om det, men b e f a $1 \mathrm{e}$ det, kunde han ikke. De danske Lærere besluttede saa ikke at deltage i Festen.

$\mathrm{Nu}$ sendte imidlertid Politimesteren Rektoren en Skrivelse, hvori der paalagdes ham at betjene sig af Danebrog.

Han blev yderst forbitret derover, sammenkaldte Drengene og lod dem vide, at de skulde møde med "hvid - og røde Farver"; "dog kunde det være det samme, om det hvide eller det røde var øverst."

Halvdelen af Drengene mødte nu med Danebrog, men de andre med hvid- og røde Strimler. Disse blev konfiskeret af Politibetjentene, idet Rektor maatte befale Drengene at rive dem af.

„De tyske Lærere vare i yderste Harme herover og ignorerede os Danske aldeles, som om vi havde været Anstiftere hertil. Saaledes gik Toget igennem Byen, Drengene tildels med bare Fanestokke, de tyske Lærere paa den ene Side af Gaderne, de danske paa den anden, Grünfeld bortfjernede sig helt.“

Rektor klagede til Amtmanden, der spurgte Politimesteren, hvorledes han kunde forbyde "die Landesfarben". Denne svarede, at han kun havde forbudt Brugen af „ikke autoriserede Faner". Rektoren ytrede, at hvis Politimesteren sendte en Betjent, vilde han kaste ham paa Døren.

"Saaledes gik det med Flagene, og det kunde naturligvis ikke undgaas, at det blev til en Skandale over hele Byen" (27. Juli 1854).

I December kom Rektor og Konrektor paa Lærermødet med det Forslag, at „ekspedere" de tre Dansktimer ud af Quinta: de var overflødige og skadelige for Bornene, idet disse forvekslede dansk og tysk Ortografi, og de kunde let som voksne indhente 
det forsømte. Manicus og Blichert opponerede kraftigt, og de andre turde ikke gaa videre, „men Lysten havde de“. Da Manicus ytrede, at Dansk blev stadig vigtigere i Slesvig, saavel for Embedsmænd som for Borgere, „opstod der en frygtelig Larm; Professoren sagde, at her vare vi syd for Demarkationslinien, her var ingen danske Embedsmænd, her var kun dansk Militær, og han haabede, at Tiden vilde komme, da ogsaa dette blev anderledes. Det sidste mumlede han mere, end han sagde det højt, men jeg hørte det tydeligt nok. Jeg maa sige, at jeg ikke før har set de Herrer optræde saaledes animost og offensiv mod det Danske. Professoren paaduttede mig i sin Harme, at jeg ønskede vel at udrydde det tyske Sprog aldeles... Men vore Kollegers Færd i denne Henseende hænger unægtelig sammen med de øvrige Tyskeres Stemning her i Byen under Forhaabning af et tysk Ministerium Scheele.

Under disse Omstændigheder er det naturligt, at vi længes mere efter en ny Rektor end før, og navnlig efter en saa energisk Mand som Ingerslev, ${ }^{8}$ ) som kan bringe det hele til Ro og Orden. Vi danske Kolleger have med Flid og Forsigtighed afholdt os fra alle Angreb, alle Moder eller Lejligheder til Sammenstød med de andre; men ved at træde saa aabent og sluttet frem mod den danske Retning hernede, maa de naturligt vente at faa Svar paa Tiltale. Naar det engang i Tiden kunde opnaas, at hele Skolens Organisme blev indrettet i Overensstemmelse med Haderslev og Flensborg, og Dannelsens Retning lededes mod Nord, saa vilde der være umaadelig meget vundet for den danske Sag, ligesom der nu er umaadelig meget tabt.“ (13. December 1854).

Nogle Maaneder derefter havde Manicus og hans danske Kolleger jaget Rektor og Konrektor trætte: i 1855 søgte og fik Rektor Jungclausen sin Afsked, efter at have staaet 41 Aar i Kongens Tjeneste ( $\dagger$ 1860), og Konrektor Henrichsen lod sig forflytte til Altona.

") C. F. Ingerslev (1803-1868) Rektor i Kolding. Da Kolding lærde Skole netop ved denne Tid blev nedlagt (for at støtte Haderslev), var det naturligt at tænke paa ham. 
Det har ikke været let at være loyale tyske Embedsmænd i de Tider. Det var svært at være Kolleger medSlesvigholstenerne før 1850 , men de har vist syntes, at det ikke var lettere at være Kolleger med Danskerne efter 1852.

De havde det som to Fingre mellem Træet og Barken.

$\mathrm{Nu}$ endelig kunde Domskolens Ledelse blive dansk.

Det blev dog ikke Ingerslev, der blev Rektor, men $\mathrm{S} ø$ r e n Povelsen.

\section{Rektor Povelsen og Lærerne}

Inden vi omtaler den nye Rektor nærmere, skal Skuepladsen for Kampen for Danskhed her længst mod Syd lige nævnes.

Domskolen laa fra 1842 (da Johannes Ewalds gamle Skole blev revet ned) i en gammel Adelsgaard paa Sydsiden af Domkirkepladsen; i det 18. Aarhundrede havde der været Waisenhus (efter 1864 blev der Statsarkiv).

Fra dens Vinduer kunde man over Pladsen (der indtil for et Par Aartier siden havde været dækket med Ligsten) se over til den skønne gamle kullede Domkirke.

Søren P ovel s e n var født 24. Aug. 1810 i Alsted ved Sorø og fik snart sit Hjem i denne By, idet hans Fader blev Godsinspektor ved Akademiet. Fra sit 10. til sit 12. Aar gik han i Skole i „Borgerdyden“ i København under Rektor Michael Nielsen, men da Sorø Akademi blev oprettet, kom han hjem og gik i Skolen der. 1828 blev han Student og tog fat paa det filologiske Studium, hvor navnlig Madvig fik Betydning for ham. Men ganske særlig, siger han, tiltrak Lærerens Kald ham, og allerede 23 Aar gammel kom han til „Borgerdyden“ paa Christianshavn. Her kom han til at staa Bestyreren Niels Bygom Krarup nær, boede to Aar i hans Hus og tog sig af Opdragelsen af de mange Kostskoleelever, som boede der. 1842 blev han Adjunkt ved Sorø Skole. 1845 fik han Orlov og tog den filosofiske Magistergrad. Da Sorø Akademi blev nedlagt, søgte han og fik Stillingen som Overlærer ved Aalborg 
Katedralskole (1847). Her virkede han 7 Aar. Sin pædagogiske Interesse dokumenterede han ved et Par Afhandlinger Om Lydighedens Betydning for Opdragelsen og Om Opdragelse til Sandhed (Aalborg 1848. 1850). Naar han i 1855 blev udnævnt til Rektor ved Domskolen i Slesvig, skyldtes det sikkert delvis, at han havde vist Interesse for Undervisningen i Tysk (1853 havde han udgivet en Tysk Læsebog for Begyndere) og skrevet en Afhandling om De udvidede Skoler og Undervisningen i Tysk.

Hvorledes Søren Povelsen var rustet i den svære Gerning som dansk Mand at lede en tysksproget Skole i en tysksindet Egn $i$ en opfanatiseret Tid, vil fremgaa af det følgende. ${ }^{9}$ )

Af største Betydning var naturligvis Rektors Forhold til Lærerne, ja man kan sige, at et godt

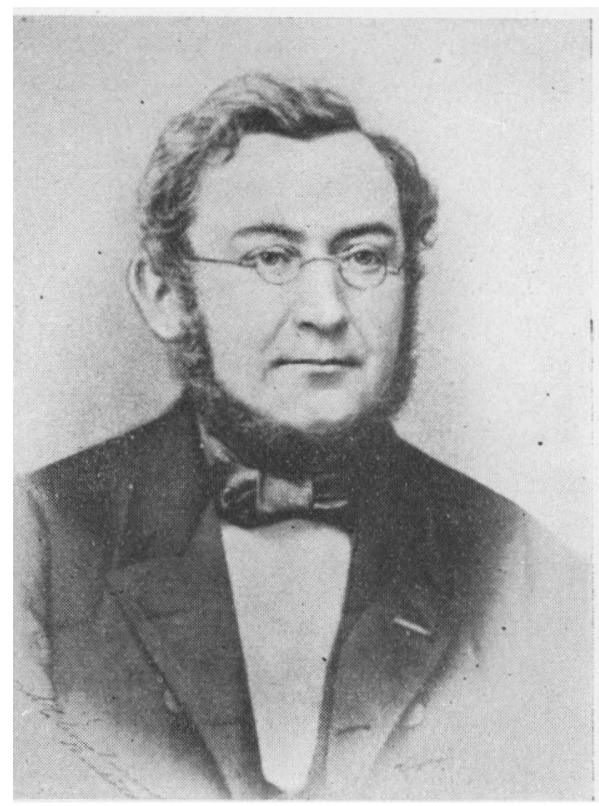

Rektor Søren Povelsen (1810-1875)

Forhold og nært Samar-

bejde var en Betingelse for, at det svære Forsøg skulde lykkes.

Da Povelsen tiltraadte, fandtes der (foruden ham selv) tre tyske og fire danske Lærere.

Vanskeligst (skulde man mene) var Forholdet til de tyske.

Man mærker, hvorledes han - forstaaeligt nok - straks stiller sig noget en garde overfor dem:

„Jeg vil ikke trætte Dem ${ }^{10}$ ) ved at fortælle om de Repliker,

9) Hovedkilden er Povelsens Breve til Regenburg. (Rigsarkivet).

19) Regenburg. 
jeg har vekslet med Hinrichsen") og de andre Tyskere, skønt flere af dem have været ret mærkelige og have bragt mig til den Overbevisning, at de gode Herrer ikke ere farlige Modstandere i aaben Mark, naar jeg blot passer paa mig selv og saa meget som muligt undgaar at træde enten altfor myndigt eller altfor beskedent op.

Endnu har jeg ikke mærket, at jeg har stødt Tyskerne, skønt jeg — under en yderst gefällig Form - har haft Lejlighed til at sige den brøsigste af dem $-\mathrm{Hr}$. Loren $\mathrm{z}^{12}$ ), en Holstener, 5 . Lærer - nogle højst fornødne Sandheder og i Conferencen ikke just tog lempelig paa ham. De gode Herrer kunne taale en Del.“ (26/2 1855).

Selv om Rektoren i Begyndelsen fandt, at de tre tyske Lærere var temmelig tamme, kunde det dog hænde, at der faldt skarpe Bemærkninger. I Anledning af, at Rektor ønskede nogle af Byens Honoratiores til Censorer, bad han Lærerne om at foreslaa ham nogle dertil skikkede. Grünfeld, en af Tyskerne, foreslog da den tyske Realskolebestyrer og „den ersten Amtssecretair Andresen “. Rektor gjorde Grünfeld opmærksom paa, at Andresen skulde være kompromitteret i Oprørstiden, og Grünfeld svarede: "Ja, men han har faaet en særegen Benaadning". "Jeg ytrede da - hvad jeg ogsaa en anden Gang svarede C. Johansen, da han $i$ et lignende Tilfælde sagde: „Det passerede maa dog engang glemmes“ —: „Det glæder mig som Kristen, at H.M.s Naade har friet Hr. Andresen fra Tugthuset eller hvad Straf hans Deltagelse i Oprøret ellers maatte have medført; men Skolens Rektor kan ikke - uden at paadrage sig sine Foresattes fortjente Dadel - sætte en saadan Herre paa samme Liste som General Thestrup og andre tro Undersaatter og agtede Medborgere“. „Naturligvis indbød jeg ej heller Realskolens Bestyrer." (11/7 1855). Povelsen tilføjer, med nogen Skadefryd:

11) H. H. H. Sydslesviger. Ansat ved Skolen 1854-56.

12) C. W. J. Lorenz Friser. Ved Skolen 1853--55. 
„Næste Nat sov hverken Grünfeld eller hans Kone, og Andresen, der havde begyndt at hilse mig, hørte op dermed."

De to her nævnte Tyskere - den tredie skiftede ofte -- var af vidt forskellig Natur.

Grünfeld, en loyal Slesviger, havde været ansat ved Skolen siden 1844. Han havde gennemgaaet de svære Aar før og under Oprøret, sine Kollegers "Spott, Hohn und selbst Verachtung“, og de store Disciples Indstilling var ikke anderledes. Efter Slaget ved Isted gav Folkestemningen imod ham sig Udslag i, at hans Ruder knustes.

Han var en dygtig Lærer, seminarieuddannet, men der gik lang Tid, inden Povelsen lærte at paaskønne ham, og han var undertiden haard i sin Mund mod ham.

Af en helt anden Slags var Christian Johansen. Han var født paa Amrum og gik i Øens Landsbyskole. Efter Konfirmationen blev han Hjælpelærer paa Sylt, og efter at han tre Aar havde "gelehrt und gelernt", fik han Ansættelse som Lærer paa List. Ligesom Læreren før tog Præsten her sig af hans videre Uddannelse, og i 1844-46 gennemgik han derpaa Seminiariet i Skaarup. Efter nogen Lærergerning andetsteds (i Slesvig) blev han 1853 ansat ved Domskolen, da Forberedelsesklassen oprettedes.

C. Johansen var en fortræffelig Lærer med en særlig Evne til at fortælle. At han forbandt levende Interesse og Utrættelighed med at virke stærkt paa Børnene, kunde Rektoren nck se. Men han var blottet for Kendskab til og Interesse for dansk Aandsliv og Kultur, medens han var opfyldt af Beundring for Tysklands aandelige Frembringelser, særlig paa det religiøse Omraade. Følgen var, mente Rektoren, at han „fylder Disciplene med et Indhold, hvorfra netop d e $t$ er udelukket, som ligger Drengene $i$ et dansk Land nærmest, og han meddeler dette Indhold $\mathrm{i}$ den Form, hvori de bibelske Historier sædvanlig fremstilles .... Det er let at tænke sig, hvad Følgen af hans Indflydelse paa smaa Drenge maa blive. Deres Ubekendtskab 
med vor Nutid og Fortid gaar derfor ogsaa til det Utrolige. Blandt de 24 Disciple i begge Forberedelsesklassers Afdelinger var der kun et Par Stykker, der kendte Tordenskjolds Navn.“ (26/7 1858.)

Rektoren lagde ham paa Hjerte, at han maatte forandre sit Standpunkt, "dersom vi med Fornøjelse skulde kunne samvirke“. I rum Tid talte han derpaa "med Flid" ikke med ham. Derpaa stillede han Kravet: C. Johansen skulde benytte en Forstandsøvelsestime til at forklare Forberedelsesklassen, at Beboerne af Slesvig, enten de talte Dansk eller Tysk, var Danske, at vort Fædreland er Danmark, vor Konge den danske Konge, vort Flag Danebrog. Det skete ikke. Rektoren mindede ham derom. Johansen mente, det var raadeligst saa lidt som muligt at berøre saadanne Spørgsmaal. Hvad Rektoren ikke mente. Johansen ytrede saa, at hvis han i en saadan Time kom i Varme, kunde han ikke lade være med - naar han omtalte Majoritetens tyske Modersmaal - at prise den Lykke at have tysk "Sprog og Nationalitet", hvilket ikke hindrede i at være tro danske Undersaatter ( $1 / 7$ 1862). „Efter at han paa lignende Maade i en hel Times Samtale havde vist tydeligt nok, at han hverken havde opgivet en god slesvig-holstensk Tro eller Haab, sagde jeg ham ganske tørt, at det under disse Omstændigheder kunde bero med den omtalte Forstandsøvelse".

Rektoren tog saare haandfast paa denne Modstand. Først indskrænkede han hans Religionstimer til de to nederste Klasser. Christian Johansen kom "fast grædende" til ham med de Ord: "So darf ich denn nicht mehr zur Schule gehen mit meinem Lutherischen Katechismus!" og han forsikrede under sin "Jeremiade“, at han gerne vilde bo slet og spise slet og gaa slet klædt, naar han kun maatte undervise i Katechismus, hvortil Rektor, noget ubarmhjertigt, svarede, at han jo kun behøvede at søge en Ansættelse, der svarede til hans Uddannelse; det var let nok. (6/2 1859).

Senere blev han bcrøvet sine Ekstratimer og henvist til de „indifferente Fag, Regning og Skrivning“. „Herefter skal han faa 
sin Ret, men heller ikke mere; maaske han da lader sig bevæge til at fortrække.“ (1/7 1862). „Det bliver mig for hver Dag vanskeligere at benytte $\mathrm{C}$. Johansen, jeg maa gøre ham saa uskadelig som muligt. Skolen har desværre allerede liden Betydning nok lige over for Hjemmet og den daglige Omgang; desto vigtigere er det, at Børnene $i$ det mindste i Skolen utvivlsomt modtager loyale Indtryk" (3/3 1861).

Rektor mente, at han direkte modarbejdede sin Skole. "Han gaar næsten som en Spion om med os". Tysksindede Elever, selv af de overste Klasser, sluttede sig til ham og modtog undertiden Privatundervisning i Tysk hos ham, „og han gør naturligvis sit Bedste for at skrue dem op til tysk Svulst og Styltegængeri“. (6/2 1859).

Han mistænktes for at agitere mod Domskolen og for, at Forældre skulde sætte deres Børn i den tyske Realskole, og i hvert Fald havde han den Dristighed at tage Timer hos Konkurrenten og Modstanderen, uden at spørge eller underrette Rektoren derom. Paa Lærerværelset, hvor han ellers kun sjældent aabrede Munden, udtalte han, at han haabede, at Lærernes Andel i Skolepengene til Paaske vilde synke fra $9^{1 / 2}$ til $7 \mathrm{Rd}$. maanedlig pro persona, „naar Disciplene gaa ud, og ingen optages“. (7/11 1862).

Men nu nærmede den store Afgørelse sig ogsaa.

Underligt og sørgeligt er det, at Povelsen, kun et Aar efter at han var kommet ned til Slesvig, kunde skrive, at den eneste Modstand, der havde mødt ham dernede - eller i hvert Fald den eneste Modstand, der havde gjort ham ondt, - var udgaaet fra de danske Lærere.

Vi skal først følge hans egen Skildring af Striden (18/4 1856).

Som den Ordenens og Reglementernes Mand Povelsen var, havde han udarbejdet Forslag til en Instruks for Latinskolen i Slesvig om Forholdet mellem Rektor og Lærere, og deres Myndighed og Beføjelser. Da dette havde cirkuleret mellem de tre første, erfor han „med Forundring“, at $H$. N. Lorenzen, Sub- 
rektoren, havde taget en Afskrift, og at han og Konrektor Dr. Maricus havde indbudt Blichert til at forhandle med dem.

„Jeg søgte Lejlighed til i Privatsamtaler at godtgøre for Manicus og Lorenzen, at Grundanskuelsen i Udkastet er den, der hersker i Kongerigets Skoler. Paa Dr. Manicus vare alle Forestillinger spildte. Han paastod, at en Skoleforfatning, i Følge hvilken Lærerne kun havde raadgivende Stemme, maatte kvæle al god Aand og være uforenelig med den Selvagtelse, Lærerne maatte være besjælet af for at kunne virke noget dygtigt".

Rektor henviste til sine 23 Tjenesteaar (hvoraf 13 i kongelig Tjeneste) under en saadan Forfatning; han havde ikke mærket noget til, at Aanden var svækket eller kvalt hos Lærere eller Disciple. Det var forgæves. „For alt, hvad jeg kunde sige, stoppede han sine Ører og gentog, at man her ikke var vant til sligt".

$\mathrm{Nu}$ haabede Rektor at kunne indvirke paa de andre danske Lærere, men ogsaa heri blev han skuffet, thi Manicus, Lorenzen, Vilhelm Johansen, Muusmann og Preyss holdt før hvert Møde Privatmøder, hvor de „ophidsede hverandre ved Deklamationer mod Udkastet“. 5 var altsaa enige forud, og „saasnart de tre Tyskere mærkede, hvorledes det var fat, fulgte de dem gennem tykt og tyndt".

„Rigtignok vilde de gøre gældende, at der alene var Tale om Principper, og maaske dette Hensyn virkelig var det bestemmende for nogle af D'Hrr., men for Dr. Manicus' Vedkommende var det en Kamp - bevidst eller ubevidst, det ved jeg ikke - for sit, efter Rendsborg Skoles daværende Form dannede Ideal af Aanden og Tonen i en Skole mod min Skolevirksomhed, altsaa ikke saa meget mod Kongerigets Former som mod den A.and, der hersker i Kongerigets Skoler.

Jeg er ganske vis paa, at dette Præg af en ren personlig Kamp mellem Dr. Manicus som Rädelsführer og mig vilde have været aldeles umiskendelig for enhver opmærksom Iagttager, selv om en saadan ikke havde vidst, at den Utilfredshed 
med og Modstand mod min Skolevirksomhed, som her kom frem, i al Stilhed var næret af D'Hrr. Dr. Manicus, Lorenzen ug Preyss lige fra det $\varnothing$ jeblik, jeg, efter et Ophold her paa Stedet af faa Dage, høfligst tilkendegav dem, at deres Raad altid skulde være mig velkomne, men at jeg hverken var kommet herned for at lade mig lede af D'Hrr.s Erfaring eller udføre deres Majoritetsbeslutninger.

Saalænge det nu kun gik ud paa Ønsker om Forandringer i Rektors og de øvrige Læreres gensidige Forhold, kunde det vel gøre mig ondt at se den mod mig fremkaldte 8-stemmige Misstemning, men Ret til at beklage mig havde jeg ikke og gjorde det ikke heller, skønt jeg ikke lagde Skjul paa min Forundring og Utilfredshed dermed, men da Dr. Manicus, der blev modigere og modigere, vilde ignorere det retlig bestaaende Forhold og tillod sig Ytringer som, at det var unaturligt, „at den ene Lærer (o: Rektor) skulde kunne blande sig i den andens Behandling af Disciplene", da troede jeg mig i min gode Ret, idet $j \in g$ alvorlig bad ham erindre, "at jeg ikke var hans Ligemand, men hans Foresatte, hvem han skyldte Lydighed og Regnskab"“.

„Hvad jeg vilde, vidste de alle, og det kunde sammenfattes med faa Ord: Punktlig Lydighed, fremmet ved mild Tugt, og en klar, men fremfor alting beskeden Viden (ein klares, vor allem nicht dünkelhaftes Wissen)".

Men det blev ikke ved dette haarde Sammenstød.

I Paasken skænkede Dr. Manicus Rektoren „sin sidste lille Fog" (vist Afhandlingen: Et Bidrag til den danske Nationalitets Historie i Slesvig. ${ }^{13}$ ) Derefter gik Rektoren over til ham og spurgte ham, hvorledes hans varme Hengivenhed for den danske Sag kunde lade sig forene med Modstand mod den Skole i dansk Aand, han (Rektoren) arbejdede paa at grunde. Mellem Manicus' Argumenter var følgende: Karaktersystemet (det Ørstedske) indeholdt Spiren til en stærk Demoralisation; Ruder i

13) Dansk Maanedsskrift 1856. S. 186-200. 
Dørene maatte bringe Disciplene til at betragte sig som „Sträflinge"; det egentlige, aandelige Udbytte af Forfatterlæsningen gik tabt „paa den danske Maade“ : ved de meget store grammatiske Krav.

„Jeg søgte paa bedste Maade at imødegaa hans enkelte Paastande .... Men da han ikke i nogetsomhelst lod sig rokke, men med Vanens og Overbevisningens hele Styrke holdt paa sine traditionelle Idealer lige indtil det aller mindste, ja endog gik angrebsvis tilværks mod mine pædagogiske Anskuelser og navnlig mod min Fordring til punktlig Lydighed og klar Viden, sagde jeg endelig høfligt, men alvorligt: „Da for et Aar siden Dr. Henrichsen blev forflyttet, da delte jeg kun halvt den almindelige Glæde; thi jeg indsaa strax, at min Kamp mod den tyske Tradition nu vilde blive mig mindre let, da jeg vilde komme til at bekæmpe Tyskeriet $\mathrm{i}$ min gode Ven Dr. Manicus. Henrichsens Afgang har desuden for Dem haft den skadelige Virkning, at Deres store Lykke ${ }^{14}$ ) har bragt Dem til at glemme, at De endnu er en uerfaren Skolemand, hvad De næppe havde glemt, nvis De havde staaet et eller andet Sted som Adjunkt (ved Kongerigets Skoler have philologiske Kandidater ... staaet 10 Aar som Adjunkt). Dette Misforhold gør mig saa meget mere ondt, som Deres deraf opstaaede Lyst til Overgreb maa gøre mig varsommere i Benyttelsen af Deres Bekendtskab med mange Forhold, end jeg ellers vilde være. Skønt jeg indser, at netop Deres fortrolige Bekendtskab med mange Forhold supplerer mine Erfaringer, og jeg derfor i Skolens Interesse inderlig ønsker en enig Samvirken med Dem, saa maa jeg dog fremdeles stille den uafviselige Fordring, at De $i$ ethvert Tilfælde, hvor vi ere af forskellig Mening, enten overbeviser mig eller underordner Dem. Vedbliver De derimod - som hidtil - hemmelig og aabenbar at lægge mine Reformer Hindringer i Vejen, saa gælder det nu, da jeg har lært min Modstander at kende, en Kamp paa Liv og Død, hvorved jeg dog intet Øjeblik skal

14) Da Henrichsen blev forflyttet til Altona 1855, blev Manicus hans Efterfølger som Konrektor, trods hans kun 32 Aar. 
glemme, at jeg har med en brav Mand at gøre". Skønt han herover blev noget forbløffet, vilde han dog endnu insinuere, at vor Uenighed kun angik Lærernes Stilling, og han gav ikke utydeligt at forstaa, at jeg havde alt for stor Hang til at være myndig".

Municus' Fremstilling af Striden (ogsaa til Regenburg) lyder (30. Juni 1856): „Skønt der i Udkastet til den fremtidige Instruks for Hertugdømmets Latinskoler var ikke faa andre Ting, som syntes $i$ det mindste at kunne fremsættes paa en anden Maade, saa var det dog i Særdeleshed Rektormagtens Udstrækning, der gav Anledning til Diskussion. Naar den i Udkastet saa at sige hensattes saa ubegrænset som en Slags patria postestas, saa kan den unægtelig i de praktiske Forhold let føre til en Despotisme, som gør Lærernes Virksomhed, Tænkning og Ytringsfrihed afhængig af enkelt Mands Skøn og Behag. Selv ved den stærkeste Centralisation i andre Forhold er Embedsmanden dog indenfor visse Grænser selvstændig; i Skolelivet, hvor daglig fælles Virksomhed fører alle Lærere sammen til stadigt Samkvem, og hvor Rektor, om han vil, hver Dag og hver Time kan gribe ind i Virksomheden, maatte saaledes, om en saa udstrakt Magt kom i en tyrannisk og mistænksom Mands Hænder, al Tanke om fri Bevægelighed eller sømmelig Frihed blive en Umulighed. At Skolens Administration ene tilkommer Rektor, have vi været enige om; kun have vi fastholdt, at der burde tilkomme Læreren som kongelig Embedsmand en sterre Selvstændighed, ikke ligeoverfor Rektor, men ligeoverfor Disciplene, og derfor fremhævet tvende Punkter, hvor Læreren, efter vor Formening, burde have en underordnet Indflydelse paa Disciplenes Skæbne, idet der nemlig tilstaas ham Strafferet og Stemme ved Opflytning.

Saa meget er vist, at et liberalt og humant Forhold ved Skolen, som vist ene kan fremme Tingenes Gang hernede, ikke synderlig vil blive fremmet ved Instruksen $i$ sin oprindelige Skikkelse og ikke blive det nærmeste Følge deraf. Er Skolelivet under heldige Auspicier engang gennemtrængt af Tillid, gen- 
sidig Velvilje og Lyst til det fælles Maal, som f. Eks. i Haderslev, saa har en Instruks, hvorledes den end bliver, lidet at betyde. Men skal den som Lov tjene til først at opbygge en Skole, saa var det slemt, om den kun blev baseret paa Mistillid, Controlle og mulig stor Undertrykkelse af Enhvers Individualitet.

En Tanke derfor, som har ligget os her i Slesvig nær, er den, at vi foreløbig vel trængte til et Regulativ, som normerer vore Timer, Ferier o. s. v., da det gamle jo er slesvig-holstensk og forældet, men at vi mindre trængte til en Instruks; især da en saadan fælles Instruks ej er i anerkendt Kraft i Kongeriget, og naar vi skulde faa en ny, derved ogsaa let en Adskillelse fra Kongerigets Skolevæsen kunde hidføres; derimod vilde vi være glade ved at optage Kongerigets Instruks uforandret, om en saadan blev udarbejdet. Men dette er kun en Tanke og et Ønske, der mulig er uberettiget. I alle Tilfælde skulde vi vide at lyde Loven, selv om den ganske afser fra Lærernes Ønsker.“

Inden vi gaar over til en Bedømmelse af Striden mellem de to saa forskellige Mænd, skal der gives en Fremstilling af Dr. Manicus' Liv og Forudsætninger.

Emil Manicus (1823-1904) ${ }^{15}$ ) var Søn af den bekendte Angelbo Claus M., en af Danskhedens første Forkæmpere, skønt tysktalende og tyskdannet. Ogsaa Sønnens Uddannelse var helt tysk, indtil sit 19. Aar havde han næppe nogen som helst Forbindelse med Dansk. 6 Aar gammel kom han i Skole i Eckernførde, 15 Aar gammel i Rendsborg. Han voksede op med Schiller og Goethe, Herder og Wieland som sine Idealer. Holsteneren Nissen vakte i Rendsborg hans Kærlighed til de latinske Forfattere. Da han var 19 Aar, blev han Student og drev sine filologiske Studier i Kiel. Her kom han gennem sin Fader i Forbindelse med Chr. Paulsen og Flor, og hørte Carsten Hauch, der indførte ham i dansk Digtning og nordisk Mytologi.

1847 kom han til København som Huslærer hos en Embedsmand i det slesvig-holstenske Kancelli, Baron v. Liliencron,

15) Ill. Tid. 17/5 1903. Nutiden 19/12 1880. Berl. Tid. 16/5, 21/5 1904. 
og ved Hauchs Introduktion blev han indført i flere fremragende Mænds Huse. Han mindedes endnu i sine seneste Aar med Glæde og Tilfredshed disse Aar, og med en vis Selvfølelse kunde han udtale, at han under dette Ophold i København, 24 Aar gammel, først lærte at skrive og tale Dansk, men da ogsaa tilegnede sig det saa fuldstændigt, at han kunde udtrykke sig heri med samme Sikkerhed og Lethed, som om Dansk havde været hans Modersmaal.

I 1848 fulgte han P. C. Koch til Haderslev, hvor han tjente sine journalistiske Sporer som Medarbejder og Krigskorrespondent. 1850 ansattes han ved Haderslev lærde Skole, 1853 ved Slesvig Domskole, hvor han altsaa 1855 blev Konrektor.

Naar man skal bedømme Striden, maa det straks siges, at naar Povelsen fremstiller det saaledes, at han repræsenterer

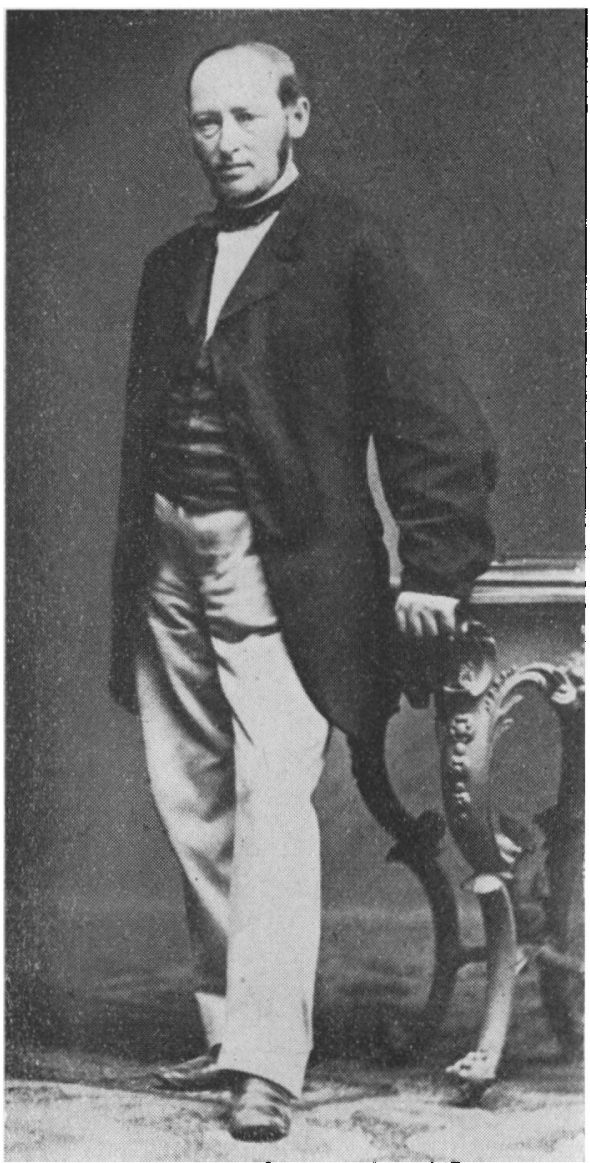

Konrektor Emil Manicus (1823-1904)

den danske Skole og dens Aand, den anden den tyske, har han skiftet Sol og Vind saaledes, at hans Modstander har faaet begge lige i Ansigtet (som vi forestiller os dansk og tysk, synes vi snarere, det modsatte maa gælde). Nej, Grunden til Modsætningsforholdet maa søges andetsteds. 
Straks Povelsen var kommet til Slesvig, bestræbte han sig, siger han, ved ethvert lovligt Middel paa at vise sine Medlærere, at han var noget mere end primus inter pares, „hvortil et Par danske Kolleger gerne vilde degradere mig, hvis de blot kunde" (20/9 1855).

Han holdt paa sin Myndighed, krampagtigt, kan man næsten sige. Af Eleverne krævede han blind Lydighed, og det var ikke langt fra, at han krævede det samme af sine Lærere. „De underordnede Opdrageres forste Pligt er det at underordne deres personlige Overbevisning med den Selvfornægtelse, der mere end alt andet betinger det heldige Udfald af fleres Samvirken". ${ }^{11}$ )

Imod dette noget diktatoriske Princip stillede Dr. Manicus sit mere demokratiske: Samarbejde paa nogenlunde lige Fod, med fælles Bestræbelser om at naa det fælles Maal. Men Rektoren vilde eller kunde ikke forstaa ham, og Samarbejdet brast.

Det andet Stridssprrgsmaal var Undervisningen i Skolens Hovedfag, de klassiske Sprog. Her er det saa heldigt, at vi kan lade Manicus selv fremsætte sine Meninger, ${ }^{17}$ ) der unægtelig er godt farvede $i$ hans Modstanders Fremstilling.

Undervisningen har, siger han, faaet en abstrakt-videnskabelig Retning, der ikke gavner Skolen, skønt den fremtræder under Grundighedens Navn. Grundigheden, som Grammatikeren tilegner sig, ligger jo ikke alene i Undersøgelsen af grammatiske Former, men i Tilegnelsen af Aandsindholdet. Man betragter det rent sproglige som Videnskab og selv'stcendigt Formaal for Skolen, i Stedet for at huske paa, at det her hverken er mere eller mindre end et Middel, der skal underordne sig den almindelige Dannelse. De klassiske Sprog er det fortrinligste historiske og æstetiske Dannelsesmiddel (Povelsen citerer selv Manicus' Formulering i en Bemærkning til ham: (9/12 1857): „Deres (э: Rektors) Disciple komme til at vide mere, men de bliver ikke saa dannede").

16) Om Lydighedens Betydning. S. 35 .

17) Om Forslagene til en Reform af det lærde Skolevæsen i Danmark (Dansk Maanedsskr. 1861 I 73 ff.) 
Men heroverfor stod Rektor Povelsen altsaa ganske uforstaaєnde, det var Løshed; gik man udenfor de tiltraadte Stier, kom man ud i Uføre. Det var "dünkelhaftes Wissen“. En Undervisning, der udelukkende stilede mod gramatiske Kundskaber, den gav „klares Wissen“.

Endnu en tredie Grund til Modsætningsforholdet skal nævnes.

Povelsens ellers saa vidtspændende aandelige Interesser havde, før han kom til Slesvig slet ikke omfattet Nationalitetsspørgsmaal og Nationalitetskampen. At der var en speciel slesvigsk Mentalitet og en slesvigsk Særfølelse, som det vilde være klogt at tage Hensyn til, var ikke gaaet op for ham. „Hvad er vel overhovedet $\mathbf{i}$ de allerfleste Tilfælde en Sydslesviger andet end en (ofte maadelig) tysk Oversættelse af en dansk Mand!“

Til Hjælp for ham her har der ikke kunnet tænkes nogen bedre Mand end Manicus, der jo selv var Sydslesviger og desuden af Selvsyn kendte de tyske Skoler saa godt (ogsaa Subrektor H. N. Lorenzen var Slesviger - fra Graasten). Men naar Povelsen straks saa lidenskabeligt frabeder sig d'Herrers „Erfaringer", er det sikkert meget deres Raad som Slesvigere. Den „lille Bog“, Manicus gav Rektoren efter det store Sammenstød: Et Bidrag til den danske Nationalitets Historie i Slesvig, handler netop om Domskolen i Slesvig de sidste 300 A ar og vil vise, paa hvor fremmed en Jordbund den tyske Dannelse faldt, og hvor tydelig Modstanden har været, som Strømningen sydfra mødte. Som Resultat uddrages „den Sandhed, at den sønderjydske Folkenatur overladt til sig selv i Kampen mod en overlegen Fjende, er at lignes ved de Søplanter, der have Rod paa Havets Bund, men alligevel synes at drages afsted med Strømmen; kommer den sydfra, saa følger den til et vist Stykke denne Retning; og kommer Strømningen nordfra, saa drages den denne Vej, skønt langsomt, og Plantens Rod staar endnu paa samme Sted".

Men Rektor lod sig lige saa lidt overbevise ved Konrektors skrevne som ved hans talte Ord. Han holdt stadig fast ved sit: 
„Jeg vil gavne den danske Sag ved at grunde en god dansk Skole med tysk Undervisningssprog og væsentlig tilstræbe dette Maal paa samme Maade og ved samme Midler, som hvis jeg var blevet Rektor i Aalborg" (18/4 1856).

Til yderiigere Bedømmelse af de to kan det have sin Interesse at se, hvorledes Forholdet senere udviklede sig.

Efter at have fortalt om det store Sammenstød, hvor han havde talt om „Kamp paa Liv og Død“, slutter Rektoren: „Jeg skiltes da ogsaa denne Dag fra ham uden det Haab at have virket noget". Men derpaa fortsaite han: „Desto glædeligere blev jeg overrasket, da han næste Dag kom til mig og erklærede ,at han nøje havde overtænkt vore Samtaler, navnlig den sidste, og at han indsaa, at hverken hans Stilling ved Skolen eller hans ovrige Adkomster berettigede ham til at fastholde sin Modstand. Jeg skulde derfor aldrig mere finde, at han lagde mig nogensomhelst Hindring i Vejen“. Jeg paa min Side gav ham et hjerteligt Svar, og hvad jeg sagde, det mente jeg, .... glemme det passerede kan jeg dog ikke, og det vilde vist heller ikke være rigtigt".

Saaledes blev da den store Strid afblæst og et bedre Forhold etableret. Men mere end taaleligt blev det heller ikke: „Vort Forhold har i de to sidste Aar uafbrudt været høfligt, ja paa en Maade venskabeligt; men vi ere komne til at staa hinanden fjern, og jeg ønsker heri ingen Forandring". (5/1 1861).

Denne forholdsvis gunstige Vending skyldtes udelukkende Manicus. I en saadan Situation, hvor Overordnet staar mod Underordnet, vil det altid være lettest for den første, som den stærkere, at søge et bedre Forhold oprettet; for den underordnede er det sværere, fordi han ofte $\mathrm{i}$ sin egen Bevidsthed vil føle det som en Underkastelse. Men Manicus var altsaa stærk nok til at se bort fra dette.

Da han senere (1873—96) var blevet Redaktør af Berlingske Tidende, havde han, selv da Meningerne stod saa skarpt overfor hinanden i Provisorietiden, en egen Evne til at sige sin 
Mening uden unødvendig Skarphed og uden at saare. Han sagde om sig selv: „Jeg har alle mine Dage været optimistisk anlagt, altid søgende de lyse Sider af Personer og Forhold fremfor de mørke. Denne lykkelige Naturgave har gjort mig det forholdsvis let at bevare Sindets Ligevægt og det gode $\mathrm{Hu}-$ mør, selv naar Kampens Bølger gik højt ${ }^{\text {(19 }}{ }^{\text {) }}$

Disse Egenskaber stod deres Prøve saavel i Provisorietiden som i Sammenstødet med hans Rektor i Slesvig.

Men sørgeligt var det, at Rektor ikke havde Evne til Samarbejde med Konrektor, det vilde $i$ alle Retninger have været til stor Styrkelse for det danske Arbejde i Slesvig.

En uheldig Person mellem de danske Lærere, som gjorde en Del Skade, skal endnu omtales.

Vilhelm Johansen (f. 1824) var Søn af en Skolelærer i Nakskov. Da Byens Latinskole blev nedlagt, var det Bestemmelsen, at han skulde til Søs (der var 9 Børn). Men Skipperen, han skulde med, strandede og druknede. Gode Mennesker underholdt ham i 4 Aar i Nykøbing, hvorfra han blev Student. I København maatte han kæmpe meget med Sygdom, der i Aarevis slog ham ned. 1853 blev han theologisk Kandidat, og to Aar derefter kom han til Slesvig.

Han var stadig ikke rask og derfor pirrelig og vanskelig. Dertil var han en udpræget Kværulant. Da han ogsaa var en kun maadelig Matematiklærer, indskrænkede Rektor hans Ekstratimer, men nu $(5 / 1$ 1861) var han ogsaa klar over, at Vilhelm Johansen, „trods sin store Kirkelighed“ nærede et brændende Had til ham og ikke vilde lade nogen Lejlighed til Hævn gaa unyttet hen; "men hans Miner og Ord forraader intet, han sniger sig tavs om mellem os, ligesom en Kat".

Lejligheden kom lige derefter.

Byens Borgmester, A. Jørgensen, havde lavet en Fortegnelse over de Mænd, man efter det sidste Aars Begivenheder

19) Ill. Tid. 17/5 1903 . 
havde Grund til at frygte som politiske Modstandere, samt over dem, der p. Gr. af deres loyale Optræden havde maattet lide Forfølgelse. Denne Liste havde han tilstillet et Par Venner, deriblandt Rektoren, med Opfordring til at gøre den bekendt hver i sin Kreds, og Rektoren begik nu den Uforsigtighed at lade den cirkulere mellem alle de danske Lærere.

Vilhelm Johansen tillod sig nu - uden at spørge Rektor eller give ham Meddelelse derom - at skrive denne Liste af og sende den til flere af de som farlige nævnte Tyskere. Han havde handlet efter sin Overbevisning om, hvad der tjente än danske Sag, var hans Forsvar, „ja han forekom mig", siger Rektor, „næsten at antage, at han ved dette Skridt i forsonlig Retning havde bidraget til at stemme Sydslesvigeme for en Inkorporation".

Tyskerne bragte Sagen for Retten, og den vakte stærkt Røre. Paa Lærerværelset skabte den megen Bitterhed, og de fleste vilde ikke hilse paa Vilh. Johansen, men "Christian Johansen skjuler kun daarligt sin Glæde over den Fare, der truer vor Skole, og er yderst intim med sin Navne“. (28/9 1861).

Dertil kom, at han paa offentlige Steder, hvor han ofte sad, udtalte sig nedsættende - sagde man - om sine egne og sit eget, f. Eks. at det var ønskeligt, om Preusserne snart kom og jog „den ganzen Plunder" nordpaa.

Tilsidst havde han den Dristighed at indsende Klage til Ministeriet for Slesvig over Kollegernes Optræden over for ham.

$\mathrm{Nu}$ anmodede Rektor Regenburg om, at Irettesættelsen maatte blive saa drøj, som han havde fortjent den. Han maatte da være „en endnu større moralsk Pjalt, end han er", hvis han ikke søgte sin Afsked.

Da Ministeriets Skrivelse var kommet og han havde læst den, var hans Forbitrelse stor, baade mod Regeringen og mod Rektor. Han vilde gaa til Pressen. „Mig truede han særlig med Gengældelse paa den yderste Dag, men foreløbig dog med Avisartikler." (14/1 1862.)

Der meddeltes ham Afsked fra 1/4 1862 „i Naade“. 
Det havde været bedre for Slesvig Domskole, om han var gaaet til Søs.

Naturligvis giver det et noget eensidigt Billede af Forholdet, naar kun Stridighederne fremstilles. Det er da heller ikke saa sjældent, at Povelsen udtrykker sin Tilfredshed med Udviklingen. Saaledes idet han (5.Jan.1861) ser tilbage paa Aaret 1860: „Der er kommet større Enhed i Lærernes Samvirke. Af de 12 Medlemmer understøtter de 7 ærligt mine Bestræbelser. Enig med mig $i$ alt væsentligt, udtale de sig frit og bestemt, hvor de have afvigende Meninger om Enkeltheder, og vi kommer fortræffeligt ud af det.“

Men en Samlingens Mand var Rektor Povelsen ikke, det Fællesskab, den societas schola, der altid er nødvendig, men særlig var det hernede mellem de Tyske, kunde ikke skabes under hans Ledelse.

\section{Disciplene}

Rektor Povelsen mente, at „Lærerne af den tyske Skole anse som bekendt en vis Grad af Tøjlesløshed og Raahed (hos Disciplene) som uadskillelig Følge af aandelig Modenhed og Myndighed, og anse det ej for at være for dyrt betalt at kobe de sidste for Indrømmelsen af de første." (30/4 1858).

Heroverfor satte han "vor Skoletugt", den blinde Lydighed eller Lystren. Den naturlige Modsætning, der vel findes overalt, mellem Skolen, der maa lægge visse Baand paa den voksne Ungdom, og denne, der ønsker at tage sig visse Friheder, gjorde han til en national Modsætning mellem Dansk og Tysk, et farligt Synspunkt, der nok kunde faa en og anden til at identificere Dansk med Tvang og Tysk med Frihed.

Denne "tyske Surdeig“ bestræbte han sig lige fra Begyndelsen paa at faa uddrevet.

Da han kom til Skolen, „svirede“ Tertianerne og røg Tobak 
paa Gaden; det fik han snart afskaffet. Noget senere fik han en Sekundanerklub forpurret, der samledes paa en Restaurant.

Men saa skete der noget, der blev Forpostfægtningen til det store Slag.

Fredag den 9/4 1858 var 4 Sekundaner, der ellers var gode Venner, samlede paa den enes Kammer for at forberede sig. Pludselig tog de 3 af dem den 4., kastede ham paa en Sofa og begyndte at besmøre hans Ansigt med Helvedessten, som en af dem havde købt for sine Vorter; det skulde blive til Knebelsbart og Bakkenbart. Han forsvarede sig, saa Sofaen gik i Stykker; men Prydelserne fik han, og han maatte gaa med Antydninger deraf i 14 Dage. Næste Dag, da de tre Syndere havde tilstaaet, tildelte Rektoren dem i Klassens Paasyn hver 6 Slag af Spanskrøret - de var henved 18 Aar gamle. - Forbitrede sagde de til deres Kammerater, at de vilde "afgaa fra Skolen“, og tog Lørdag Eftermiddag hjem til deres Forældre (i Husum og Flensborg). Det blev dog denne Gang ved Truselen.

Næste Aar mente Rektor at have faaet "Værtshusbesøget" omtrent indskrænket til Prima. Forbyde det vilde han ikke, saalænge han ikke havde Midler til at forhindre det. Men han advarede. „Desværre maatte jeg snart erfare, at man ikke brød sig om mine Advarslers Indhold, men søgte af deres større eller mindre Alvor at slutte, hvor mange Favne Taalmodighed, der endnu var tilbage. Dette gjaldt ogsaa m. H. t. mine Advarsler mod Uflid, Studshed mod Lærerne o. m. a. Jeg sagde dette rentud og tilføjede, at de herefter ingen Signalskud maatte vente“. (11/6 1859).

Man mærker Irritationen, og Katastrofen kom da ogsaa snart.

Naar Disciplene skulde aflevere et skriftligt Hjemmearbejde, plejede de at aflevere det meget upræcist, som det nu passede dem, idet de brugte Frikvartererne eller en anden Lærers Time til at gøre det færdigt. For at forebygge denne Uskik, befalede Rektor, at de hver Morgen Kl. 8 skulde aflevere hvert Hjemmearbejde til Inspektor ( 0 : stikke det $i$ en Kasse). Dette 
generede Primanerne, „som ikke havde Lyst til Regelmæssighed". En af dem, Hinrich Wolf, beholdt sin Stil til Kl. 12 og svarede, at det plejede han at gøre for at se Stilen efter i Pauserne.

Da faldt Hammeren, og Rektor gav ham (vel i Hidsighed) en Lussing. Han var henved 24 Aar gammel.

Hermed var „den uforsonlige Modsætning mellem min pædagogiske Grundanskuelse og de herværende, tyske Traditioner endelig kommet til Udbrud" og nu skete Oproret (som Rektor selv kalder det).

Primanerne fandt, at Klassen - ved at en af dem havde faaet en korporlig Afstraffelse - var vanæret (entehrt), og alle Disciplene udeblev fra Skolen. „Sie haben sich vermessen, sich an ihren Rector rächen zu wollen, und in ihrer Verblendung den Angriff gegen die unschuldige Domschule gerichtet“. ${ }^{20}$ )

Angrebet var saa meget farligere, som Disciplenes Forældre havde givet deres Sanktion, og rundt om i Byen kunde de høre fornuftige Folk sige: „Sie würden an ihrer Statt dasselbe gethan haben".

Derpaa fulgte efterhaanden Udmeldelse af omtrent hele Klassen (6); kun to blev tilbage.

Rektor henstillede til Ministeriet, at Wolf og to andre bortvistes fra Skolen (Udmeldelsen kunde ikke antages, hævdede han, før de havde afbødet deres Forseelser). Men som et Træk derimod blev de, før Ministeriets Afgørelse forelaa, immatrikuleret ved Kiels Universitet.

Paa en underlig bagvendt Maade regnede Rektor det skete for en Sejr: „Vi beholde kun to Primanere, og jeg vil i Juli med allerstørste Varsomhed flytte op, maaske kun en eneste. En saadan lille udrenset Prima, som strengt holdes fra Værtshusbesøg og deslige, vil medi Guds Hjælp afgive en bedre Stamme. I de nærmeste Aar tænker jeg mig desuden det Tilfælde, at de tysksindede Fædres Sønner sendes til Rendsborg eller anden

${ }^{\text {20) }}$ Rektors Ansprache an die Schüler. (Programmet 1859. S. 32), der er Kilden her slammen med Brevieme. 
holstensk Prima, for ikke at miste de kære Primanerrettigheder. Vi beholder da i hvert Tilfælde Sønnerne af de danske Forældre - for Tiden hver 4. eller 5. af det hele Antal (11/6 1859). Men for at sikre os denne Sejr var en bestemt og alvorlig Afgørelse fra Ministeriet nødvendig, „under den Forudsætning nærer jeg det sikre Haab om, at det skete vil kunne bringe os et stort Skridt fremad i dansk Retning".

Ministeren fandt det ønskeligt, at de tre bortviste tog Eksamen ved Domskolen som Privatister, extraordinært.

Efter et Sammenstød saa kraftigt var det udelukket, at Forholdet mellem de store Disciple og Rektor kunde blive godt, og i næsten hele Forældrekredsen og videre ud havde det forøget Animositeten mod Skolen.

Den næste Affære skulde faa et tydeligere politisk Præg.

Christian Schultz, Søn af Postsekretæren i Eckernførde, fejrede $\sin 17$ Aars Fødselsdag sammen med en Søn af Godsejer Weiland, Amtmand Davids og Stiftsprovst Martens og en Boghandlerlærling. De drak Punch og sang, blandt andre єn, hvor Slesvigs Herlighed prises. Men i Stedet for Omkvædet: "O Schleswig, mein geliebtes Vaterland" sang de "O SchleswigHolstein, mein teures Vaterland", mange Gange, og det foregik i et Værelse til Gaden i en lav første Sal, saa det lød stærkt, og Folk standsede udenfor Huset. "Heldigvis" kom tre Betjente forbi; de gik derop. Ungdommen vilde først nægte, dernæst forsøgte de at overtale Betjentene til at tilbageholde Klagen; forgæves. Rapport under Eds Tilbud, Lærlingen blev - af Hensyn til hans Ungdom - dømt til 24 Timers Vand og Brød. Afstraffelsen af de 4 Disciple overlod Politimesteren til Rektor. Denne suspenderede de 4's Skolegang og dekreterede dem Husarrest indtil videre. Derpaa fastslog han følgende, som Forældrene skulde gaa ind paa ved en Revers: 1) de to udenbys skal flytte bort fra deres Vært, Værtshusholder Martensen, og den nye Vært approberes. 2) Alle 4 maa - indtil Paaske, 4-5 Maaneder - ikke forlade Huset efter $5 \mathrm{Em}$., undtagen i Selskab med Fader (Værge). 3) I Juleferien maa de ikke rejse 
bort fra Byen uden Rektors udtrykkelige Tilladelse, og denne vil afhænge af deres Opførsel i Mellemtiden. 4) Martens mister sin fri Skolegang og skal desuden de forste Uger paa de Eftermiddage (Onsdag og Lørdag), Klassen ellers har fri, arbejde paa Skolen under Rektors Opsigt, fordi han, medens han havde Husarrest, hver Dag var gaaet ud og besørget Informationer. 5) Schultz, der var øverst i sin Klasse, sættes nederst. Desuden fik han under Forhøret paa Kontoret under fire Øjne et Far paa sine Øren. „Unægtelig er det hele en meget mild Straffemaaler", slutter Rektor.

Schultz og Weiland vilde ikke flytte fra deres Vært, og de maatte saa forlade Skolen.

Men Rektor sagde: „Bryderier og Skuffelser, langt fra at redslaa mig, snarere opliver mit Mod til Kamp mod det Onde“. (Nov. 1861).

Den sidste Affære, der kendes, hvirvlede ikke saa meget Støv op.

Naar Drengene gik til Konfirmation, plejede de at faa visse I.empelser i Skolelektierne. Da disse var meddelt dem, var der en Dreng, Hermann Schnepel, der henvendte sig til sin Lærer, J. Helms, om Fritagelse ogsaa for den danske Stil (2/2 1863).

Helms afslog det kort, han havde jo faaet Besked.

Men Schnepel, „der i det hele er en raa Dreng“, vilde ikke nøjes dermed, men spurgte: „Warum sollen wir überhaupt die dumme dänische Sprache lernen,, die spricht ja doch niemand?"

Helms bad ham rolig at afholde sig fra slige dumme Bemærkninger. Men Drengen replicerede: „Die Bemerkung ist gar nicht dumm!“ Helms svarede: „Din Agtelse eller din Ringeagt for det danske Sprog er en ganske ligegyldig Sag; men uforskammede Svar maa du ikke give din Larer", og gav ham 4 Slag med Spanskrøret.

Da denne Opforsel var et temmelig enestaaende Tilfælde, gjorde Rektor ikke videre derved. 
Det kunde hænde, at Povelsen udtalte Ros over Disciplene, saaledes 5/1 1861 baade for Flid og godt Forhold, og 26/7 1863 siger han: „For første Gang havde jeg alle mine unge Studenter og alle Lærerne samlede $i$ et Aftenselskab, hvor det gik meget gemytligt til, og hvor der blev sunget baade Dansk og Tysk, og hvor vi Lærere udbragte alle Skaale paa Dansk. En af de unge Studenter takkede paa Tysk, og det laa jo ogsaa nærmest".

Men alligevel -

Tilsidst i sin Ansprache efter "Oproret" udtalte Rektor Povelsen - med Bagvægt altsaa:

„Wie Gehorsam gegen das Gesetz Gottes die unerlässliche Pflicht eines guten Christen ist, und Gehorsam gegen das Gesetz des Königs die unerlässliche Pflicht eines guten Bürgers, so ist Gehorsam gegen das Gesetz der Schule die unerlässliche Pflicht eines guten Schülers. Dies war mein erstes Wort an die versammelten Schüler, und dies wird - früh oder spät - mein letztes sein".

Han havde bygget sit Hierarki op: Gud i Himlen, Kongen i Danmark, Rektoren i Slesvig, og dem skyldte den gode Kristne, den gode Borger og den gode Skoledreng Lydighed, Lydighed og atter Lydigehd. Med den Indstilling og Mentalitet kan der vindes meget, men ikke Hjerter, og selv naar man sejrer, taber man ofte.

Lige efter at han var kommet ned til Slesvig, skrev han (26/2 1855): „Det har glædet mig at se den Autoritet, jeg straks har faaet over disse velsignede (undertiden lidt for pirrelige) Mennesker". Denne Autoritet over Larerne beholdt han utvivlsomt. Men Sindets Gaver til at skabe Samling og Følelse af Fællesskab fattedes ham.

Overfor Lærere som overfor Disciple en myndig, skarp, usmidig Mand, uden Venlighed og Charme. At lempe sig frem var hans Natur imod: „Jeg tror, at man i Kampen mod Tyskheden og Tyskerne oftere har Brug for Raskhed - - selv med en 
lille Tilsætning af Hensynsløshed - end for den saa meget anbefalede Forsigtighed" (28/4 1861).

Autoritet, Myndighed, Skarphed, Ordenssans, pædagogisk Interesse, Flid, Iver - og alligevel ikke den rette Mand paa det rette Sted.

\section{Det Danske i Undervisningen}

I Kongeriget var (13/8 1850) den Madvigske Skoleordning blevet gæildende, hvorved Matematiken og Fysiken var kommet til at spille en betydelig Rolle ved Siden af Latin og Græsk, saa de omfattede $28 \%$ af det samlede Timetal mod de klassiske Sprogs 20,7 $\%$.

I Slesvig var de tilsvarende Tal 17 og 30 of.

Men det, der interesserer i denne Sammenhæng, er, hvad der gjordes for at forøge det danske Islæt i den tyske Skole.

Til Støtte for Skolen i Almindelighed blev der, straks efter at Povelsen var blevet Rektor, oprettet Realafdelinger; Undervisningen skulde være fælles $i$ de to nederste Klasser, men i de tre derover skulde der være selvstændige Klasser for Realister. Men Retningen slog ikke særlig godt an: I hele Skolen var der kun 6 (1856) til 16 (1863). Deri var naturligvis Realskolen Skyld, der jo var Tyskernes egen. Povelsen søgte at faa denne forbudt, men Ministeriet var for klogt til at gaa med til denne Tvang.

Med Undervisningen i Dansk gik det naturligvis saaledes, at det Resultat, der naaedes, blev større og større, efterhaanden som Grundlaget fra de lavere Klasser blev bedre og bedre.

Allerede 26/2 1855 kunde Povelsen skrive: „Med Undervisningen i Dansk gaar det herligt allerede i lille Quinta, og vore Primanere, som ikke have lært Dansk nedenfra, tale ikke blot meget godt Dansk, men skrive frie Afhandlinger paa en halv Snes Sider".

I Skoleaaret 1862,63, det sidste fuldstændige, naaedes der, 
efter grammatiske og sproglige Øvelser i de tre nederste Klasser, i de fire øverste følgende:

IV. Valdemar Sejer. Stykker af Peder Paars.

V. og VI. Hrolf Krake (af Oehlenschläger), Præsten i Vejlby, Juleferierne, En dansk Students Eventyr, Genboerne, En Spurv i Tranedans, Eventyr paa Fodrejse.

VII. Oversigt over den danske Litteraturs Historie. Nordens Guder, Baldur hin Gode, Svend Dyrings Hus, foruden flere udvalgte Stykker af andre betydende Forfattere. Jomsvikingasaga. Ja, man havde den Dristighed at give sig i Kast med Oldnordisk og læse 16 Sider af Hrafnkels saga.

Desuden Stile og "Exercitier“ af en saadan Sværhedsgrad, at man mente at kunne byde de Slesvig Dimittender følgende Eksamensstile: At fortælle den catillinariske Sammensværgelse (1860). Hovedtrækkene af Christian II's Historie (1861). Skildring af Amerikas fysiske Beskaffenhed (1862). Hvilke Pligter har Mennesket med Hensyn til Dyrene (1863).

Til Resultatet bidrog ikke lidet, at „Fædrelands-“, d. v. s. Danmarks-Historie blev lagt til Dansk, og at man brugte en dansk Lærebog (i de højere Klasser Allens, i de lavere Barfods).

Fremmende har det ogsaa virket, at ikke mindre end $22 \%$ af Børnene, i Reglen fra Embedsmandshjem, kom fra Kongeriget.

Til Afløsning af Preussisches Lesebuch udarbejdede Chr. C. Lorenzen,*) Adjunkt ved Skolen fra 1856, med Understøt-

*) C. C. Lorenzen (f. 1829) var fra Sundeved. Da Degnen mente at finde Evner hos den unge Bondeknøs, blev han sendt til en Skolelærer i Angel for at lære, navnlig Tysk. Betalingen for den Undervisning, han nød, var, at han selv underviste de mindre, et Sted 80 Børn 6 Timer daglig, "saa at mine frie Timer var temmelig indskrænkede«. Efter Præstens Raad bestemte han sig til at gaa den akademiske Vej, og 1 1848, da han var 21 Aar gammel, gik han ind i Sekunda i Flensborg. Efter de 3 bevægede Aar tog han til København som den første fra Flensborg i mange Aar. 1856 teologisk Kandidat, s. A. ansat ved Domskolen. 
telse af Ministeriet, en Deutsches Lesebuch, der fra 1858 blev brugt $\mathrm{i}$ de to laveste Klasser.

Af Sagnene er Halvdelen danske, af Resten er der kun et Par tyske. "Darstellungen aus der Vaterlandsgeschichte" indeholder 33 Fortællinger fra Danmarks Historie, og af „Mitteilungen aus der geographischen Beschreibung des Vaterlandes" er de 56 fra Kongeriget, 14 fra Slesvig og 7 fra Holsten. Sidste Afdeling "Vermischtes" har bl. a. Uffes Kamp, Rigsvaabenet og Vor Krigsmagt.

I Geografi lagde man Hovedvægten paa Danmarks, og Disciplene lærte at udtale de danske Navne rigtigt.

Da Povelsen jo betragtede Dansk sammenlignet med Tysk som repræsenterende det klare og koncise mod det uklare og udvandede, var han ivrig for at faa Lærebøger oversat: „En god dansk Skolebog i tysk Oversættelse er et virksomt Middel til at befordre den her ligesaa ønskelige som hidtil savnede danske Aand og Tankegang .... Hertil kommer endnu det Hensyn, at vore Lærde have et fortrinligt Greb paa at skrive gode I.ærebøger, hvilket Tyskerne $\mathrm{i}$ det sidste Decennium stiltiende have indrømmet ved som Oversættere at kaste sig over de hos os udkomne Skolebøger".

I Skoleaaret 1862/63 var man kommet saa vidt, at der f. Eks. i øverste Klasse kun brugtes 5 originale tyske Skolebøger, men 7 i Oversættelse fra Dansk (og foruden dem Oehlenschlægers Nordens Guder og Allens Danmarkshistorie). Selv havde han oversat Tregders græske Myteologi og hans græske Formlære.

Som et lille Fremstød kan ogsaa nævnes, at Povelsen (1860) opgav de tysk-latinske Klassenavne (Prima - øverste o. s. v.) og efter dansk Mønster gik den modsatte Vej med I som den laveste og VII som den højeste. Samtidig indførte han Vidnesbyrdbog og Karakterer som i Kongeriget.

Af aller største Betydning var det naturligvis, hvor Dimittenderne besluttede sig til at studere, i Kiel eller i København. 
Sikkert efter Forespørgsel fra Regenburg fremsætter Povelsen sit „Standpunkt overfor det vigtige Spørgsmaal, hvad der er at gøre for at faa vore Dimittender til strax og alene at gaa til Københavns Universitet":

1) Det eneste faste Baand mellem os og Københavns Universitet er Meddelelsen af en ensartet Dannelse, saa den ofte ordknappe og undseelige danske Grundighed fortrænger den rhetorisk-sofistiske tyske Overfladiskhed, der har blændet og bestukket selv kompetente Dommere. I Forbindelse med de danskdannede Lærere er det lykkedes mig allerede at faa dette godt igang og at neutralisere de tyskdannede Læreres lammende Indflydelse. Men Frugterne vil først vise sig, naar nuværende Quarta skal afgaas om Abiturienter i Sommeren 1863!

2) Indtil da blive de, der herfra gaa til Kebenhavn, for den danske Sag en uvis Vinding (jeg anser de "loyale Slesvigere“ for upaalidelige Venner og i paakommende Tilfælde for de farligste Fjender*) og det er kun af Hensyn til mine Disciples Fremtidsvel, at jeg søger at aabne deres Øjne for det, der er $\mathrm{i}$ deres Interesse. Jeg afholder mig fra Overtalelse, ja fra ethvert Raad.

3) Skønt jeg i mit Hjerte betragter dem, der gaa til Kiel som fortabte Faar, saa behandler jeg dem ikke som saadanne, men idet jeg omfatter alle mine Dimittender med samme Velvilje, vedligeholder jeg den venskabelige Forbindelse med Kieler Studenterne, ogsaa for i paakommende Tilfælde at kunne staa dem bi med Raad og Daad."

Som man ser et baade behersket og klogt Standpunkt.

Af de 21 (flere var det ikke!), der dimitteredes fra Domskolen 1850-1862, gik iøvrigt ikke mindre end 13 til København og kun 7 til Kiel eller et andet tysk Universitet.

*) 20/9 1855 havde Povelsen skrevet: „Saa ofte jeg hører nogen kalde sig "Slesviger" og ved dette Ord betegne sin Upartiskhed over for Danske ag Tyske, kommer jeg til at tænke paa Heroliots Ord $(8,73)$ : De ovrige Stater vare neutrale, men hvis jeg skal sige min Mening, saa betød deres Neutralitet intet andet, end at de holdt med Perserne." 
Det danske Element styrkedes stadig ved nye Udnævnelser, saa det i 1863 bestod af 8 kongerigske, 2 danske Slesvigere, 2 loyale Tyskere samt Christian Johansen.

Det virksomste Middel til at fremkalde Kærlighed til det Danske, var naturligvis selve Lærerens Person, og mellem disse var der - foruden Manicus, der allerede er nævnt - flere betydelige.

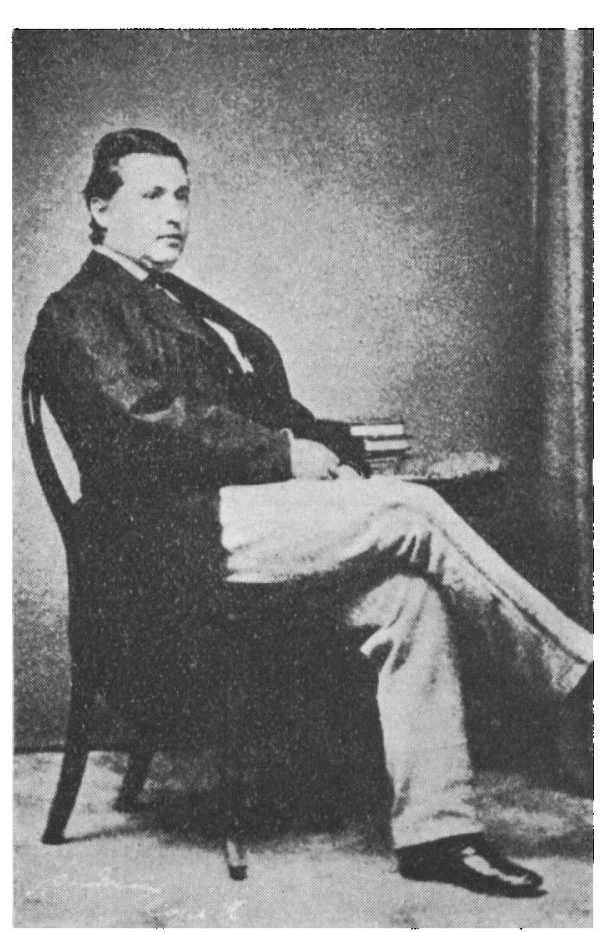

Kollaborator Peder Blichert (1828-1894)

Peder Blichert (f. 1828 i Kolding; ansat 1853) var, skrev Povelsen (2/4 1855), den Medarbejder, han satte mest Pris paa, "blandt meget andet fordi han har det bedste Humør, og skønt dansk og djærv trods nogen - dog er vel lidt af Tyskerne". Han stod højt hos Børnene, et af dem fortsatte Venskabet op gennem Aarene, kom ofte og besøgte ham, da han var blevet Rektor i Roskilde (som Povelsens Efterfølger) og Sorø, og da rejste han - der nu var høj Embedsmand -, fra Tyskland op til hans Begravelse. ${ }^{21}$ )

Morten Muusmann (f. 1822 i Aarhus, ansat 1855) skriver i sit vita i Skolens Program, at han, da han var begyndt at undervise (ved den højere Realskole i Helsingør) fik en Interesse for og en Kærlighed til Skolevirksomhed, der ofte har faaet

21) Meddelt mig af hans Datter, afd. Fru Blichert Nielsen. 
ham til at føle en levende Glæde over hans Beslutning at vælge Lxrerens Kald.

Derfor havde han ogsaa et særlig godt Tag paa Børnene (og forstod ogsaa at omgaas Befolkningen). Naar der paa Vejen hjem opstod Stridigheder mellem Drenge fra Domskolen og Realskolen, kunde han jævne disse, og det var vel at mærke ikke blot hans egne Drenge, der kom til ham med deres Klager, men det hændte ogsaa, at Realskolens kom løbende efter ham

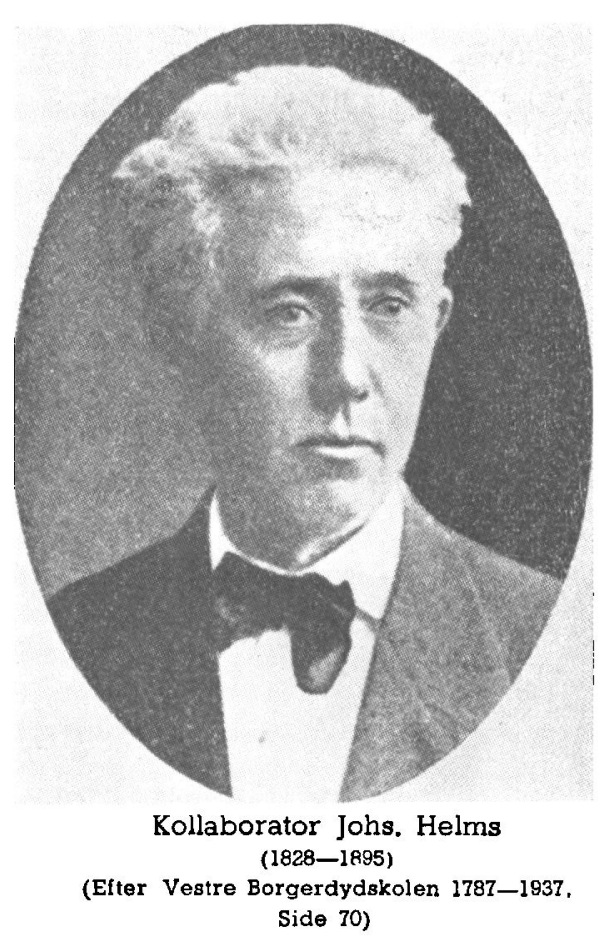

og anraabte ham om hans Bistand mod de andre (Povelsen 17/1 1858).

Men højest stod dog sikkert Johannes Helms (f. ved Slagelse 1828, ansat 1859).

Han havde som ung Student deltaget $i$ to Aars Felttog (som han senere skildrede i Soldaterliv i Krig og Fred, der indledes med „Jeg elsker de grønne Lunde"). Derefter havde han boet paa Regensen, og hans lystige Viser som Den svenske Konstabel, Prins Ferdinand og Jeg har været til Middagsmad, vandt stor Yndest.

Ham kunde Drengene naturligvis ikke staa for, hverken de danske eller de tyske.

„Jeg har stor Glæde af den danske Undervisning i Fædrelandshistorie, som er begyndt i de to Obertertier", skrev Povelsen (6/2 1859). „Disciplene deltage med et usædvanligt Liv, sæetter en $\mathbb{E r e} i$ at gøre det godt. Til dette gunstige Resultat bidrager Lærerens (Helms') vindende Personlighed, der har gjort 
ham meget populær. Men selv den Omstændighed, at "tyske“ Drenge fatte Kærlighed til - vel endogsaa af og til efterligne - et saadant Prøvekort paa en københavnsk Student, uden mindste Tilsætning af en Kieler. er ikke uden Betydning. De ere aldrig gladere, end naar de kan faa ham til at fortælle om sin Deltagelse i Krigen, og kommer der en enkelt Ytring fra en Dreng af en tysksindet Familie, som f. Ex.: Saa De saa ikke min Fader blandt Belejrerne af Fredericia? saa forstaar han med L.ethed, med en Rodomontade, der klæder ham, at svare: Nej - og det var hans Lykke! saa at alle hjertelig le paa Spørgerens Bekostning. - Det er karakteristisk, at hans Disciple sværme for Napoleon I, medens Subrektors med sure Miner høre om hans Sejre og 'Tyskernes Nederlag".

\section{Stemningen omkring Domskolen}

En Skole, der stod paa en saa udsat Post og faktisk var i saa tydelig Modsætning til Hjemmenes politiske og nationale Indstilling, Livssyn, kan man næsten sige, var naturligvis udsat for en voldsom Kritik.

Denne rettedes først og fremmest mod de danske Læreres tyske Sprog.

„Byens Tyskere ere meget forbitrede paa os danske Lærere siden de to slemme Tyskeres Afgang, ${ }^{22}$ ) og Harmen giver sig Luft i allehaande Angreb. Den eneste Beskyldning, der er lidt Opmærksomhed værd, er den, at vi generes af Sproget. Thi den er desværre sand, og jeg kan ikke faa alle mine Kolleger til at indse, at en fuldstændig Tilegnelse af Sproget er det bedste Vaaben mod vore Modstandere og det naturligste Middel til at betage Disciplene den Følelse, at vi ikke ere af deres egne“. (30/4 1855).

Selv gjorde Rektor Povelsen sit Bedste ved f. Eks. altid at tale Tysk, ogsaa til de danske Lærere i Skoletiden. Men han

\footnotetext{
22) Lorenz og Konrektor A. J. F. Henrichsen.
} 
blev ved at have sine Bekymringer: „Jeg har haft den Fornøjelse at bemærke, at Helms ikke generes af Sproget. For C. C. Lorenzen har jeg naturligvis ikke været bange. Gid jeg havde Muusmann saa vidt. Han gør sig ærlig Flid, men er dog endnu ej kommen saa vidt, at han i en Anmærkning i Klasseprotokollen kan undgaa grammatiske og ortografiske Fejl, hvad enten han lader ham "nachsitzen“ eller straffer ham „mit sechs Schläge".

Hvor krads og ondsindet Kritiken kunde være, viser det soms Dr. juris Gustav Rasch bringer til Torvs om Skolen i sin Vom verlassenen Bruderstamm (1862/63).

Hans Kilde er ofte Skolebørnene, og hvad de har skrevet op i Timerne om deres Lærere.

Hver af Lærerne bliver trukket frem og rullet i Tjære og Fjer (III 25 ff.).

Om Povelsen hedder det: Tysk taler den nye Rektor i den tyske lærde Skole højst mangelfuldt. Han gør sig heller ikke den ringeste Umage med at lære Sproget. Og hvorfor ogsaa? Grænseløs Foragt for tysk Dannelse og tysk Kultur er jo Grundtrækkene hos ham, og hans Mission bestaar netop i at fortrænge alle tyske Elementer af den slesvigske Ungdoms Dannelse. Man siger, at denne lærde Herre benægter Tysklands Eksistens positivt og har givet en Lærer, der havde et Kort over denne Uting hængende, Ordre til at tage det væk, og sine Primanere skal han have truet med: han skulde nok faa pillet ud af de Slesvigere at tale om deres Schiller og deres Goethe.

Manicus er en i enhver Henseende indifferent Person, tør og kedelig i sin Undervisning og med ringe Evner som Lærer. Hans mangelfulde Kundskaber i det tyske Sprog var navnlig tydelige i de første Aar i Slesvig.

(Da jo Tysk var hans Modersmaal, trøstes man ved, at der dog tilføjes: in der letzten Zeit ist es damit besser geworden.)

For Peter Blichert er enhver tysk Discipel et Uhyre (Greuel), og hans Vrede faar ved hver Lejlighed Luft ved Øretæver og Prygl. Han er fuldkommen uden Manerer; hans Op- 
førsel er raa og ordinær. Siddende paa Stolen med Benene over hinanden og med Ryggen mod Eleverne finder han en særlig Crlæde $i$ at spytte paa Gulvet og paa denne Vis danne Figurer. Han er ikke uden Begavelse, men grænseløs indolent og højst overfladisk i sin Undervisning. I Græsk er den af en saa sørgelig Natur, at han ved sin Uvidenhed $i$ de elementæreste Ting gør sig latterlig selv for Eleverne i Konfirmationsalderen. At han taler Tysk højst mangelfuldt og laver de værste Brølere $i$ Grammatik, er det ikke Umagen værd at nævne.

(Blichert blev senere anset for at være en af Landets bedste Pædagoger, der styrede Roskilde og Sorø Skoler paa en mønstergyldig Maade).

Morten Muusmann er en lille Mand med fine Manérer og fint Væsen, i skarp Modsætning til den højst brutale Opførsel hos de fleste andre Lærere. Hans mange og lange Ophold i Udlandet har givet ham Pli og Politur. Men han er en eksalteret Fiderdansker, og naar Eidanismen stiger ham til Hovedet, kaster han alle sine fine Manérer over Bord.

Sønnen af en Slesvig Borger, en brav Haandværker, blev i en Time spurgt af Muusmann, hvor Byen Slesvig ligger.

"I Slesvig", svarede naturligvis den 10-aarige Dreng.

„Nej“, skreg Læreren, „i Sønderjylland i Danmark. Ved du nu, hvor Slesvig ligger?“.

Intet Svar. Drengen kunde ikke faa i sit Hoved, at Slesvig pludselig skulde være blevet til Sønderjylland. Endnu engang blev han overfuset af Læreren, men hans Svar lød: „I Slesvig“.

Rød af Raseri og Forbitrelse slog Muusmann Drengen med den knyttede Næve.

„Hvor ligger Slesvig?“

En lang Hulken fra det mishandlede Barn var det eneste Svar. Ørefigner og Næveslag Gang paa Gang igen. Endelig hørte man Drengens sagte Svar: „In Dänemark!".

(Det er den Lærer, som elsker at have med Børn at gøre, og som selv fremmede Drenge tillidsfuldt henvendte sig til)!

Helms er den geniale Forfatter af Sangen Den tapre Land- 
soldat, ${ }^{23}$ ) en Blanding af Plathed og Snak. Han udmærkede sig imidlertid ikke blot som Sanger, men ogsaa som Helt, en anden Tyrtæus. Han avancerede til Sergeant og erhvervede sig ved Isted Dannebrogskorset. Det er en ubegribelig Taktløshed at meddele Ungdommen disse Ting i Skoleprogrammet. Hvorledes Ungdommens Stemning er imod ham, behøver man vel ikke at omtale.

Han er altsaa i flere Retninger en berømt Mand, men ikke m. H. t. Dannelse og pædagogisk Dygtighed.

(Helms blev senere en elsket og agtet Bestyrer af Borgerdydskolen paa Christianshavn).

O. s. v. o. s. v. om alle Lærerne. Skolen skildres som en zoologisk Have, med lutter sære Dyr, snart latterlige af baade Udseende og Opførsel, snart ondsindede og fæle.

$\mathrm{Nu}$ er Rasch' Bog naturligvis - som man vist har forstaaet - præget af det mest indædte Had til og en stærblind Fanatisme mod alt dansk, men hans Kritik er dog et Tidens Tegn paa Stemningen, som den var, særlig op mod Afgørelsen. Selvfølgelig har der været nogle af Byens Borgerskab, der har søgt at være loyale, og der har været andre, der har set paa Domskolen som et nødvendigt Onde; deres Drenge maatte igennem den, og for deres Skyld maatte man finde sig i dette Onde. Men i vide Krese har Skolen med Held været lagt for Had, Byen har været fuld af Sladder om den og dens Lærere, og det ottende Bud har i Slesvig lydt: Du skal sige ondt Vidnesbyrd om din Næste, naar han er Danşk.

Denne Fanatisme er der ogsaa Eksempler paa mellem Skoledrengene: „Toldinspektørens Søn blev for ikke længe siden paa Gaden holdt af en Dreng, medens en anden spyttede ham ind i Munden. Saadanne Excesser ere efter min Erfaring altid Lærernes Skyld. Naar det gaar saaledes i slesvigske Skoler, tør man næppe undres over, at de danske Drenge terroriseres i Rendsborg Realgymnasium. En Søn af Krigsraad Jacobsen hav-

:3) Af Peter Faber! 
de faaet en Hue med Kongens Navnetræk. En Søn af Pastor Bolted i Bündtorp rev Navnetrækket af og spyttede i Huen, men blev ikke straffet, hvorimod han pro forma fik en Irettesættelse“ (20/8 1861).

„Skønt jeg ved, hvorledes den holstenske Ungdom indpodes Had til alt, hvad der er Dansk, saa forbavses man dog, naar et enkelt Eksempel træder én nær. Vi havde ved Juletid faaet en 10 Aars Dreng fra Pløen, hvis Moder er født i Sundeved og opdragen paa Fyen. Men desuagtet lynede Glæden ud af hans Øjne, naar der i den fædrelandske Historie var Tale om Ulykker, der havde truffet Danmark, ligesom han ogsaa en Dag jublende fortalte sin Onkel, at Historielæreren (Helms) havde sagt, at de andre "de fødte Slesvigere" var Danske, men at han som en født Holstener var en Tysker (18/3 1861).

Dr. Tryde giver sig meget af med Dr. Gayes ${ }^{24}$ ) Børn, der ere Disciple i den endnu blomstrende Realskole. Med dem taler han naturligvis Tysk, men desuagtet ytrede den ene Dreng, der er 7 Aar gammel, at Tryde fortjente Ørefigen, "fordi han talede Dansk". Saaledes lærer Hr. Gaye, der selv ikke kan, eller maaske ikke vil kunne et Ord Dansk, sine Børn at forstaa Ligeberettigelsen“ (11/11 1860).

Lærernes Autoritet, vel ogsaa undertiden deres Venlighed mod Børnene, Hensynet til de mange danske Kammerater og Tanken om, at man skulde naa et Maál ved Skoleaarets Slutning, har vel som oftest forhindret denne Stemning i at komme til Udbrud. Men hos de fleste af Ungdommen var denne Modvilje, Aversion eller maaske Had mod ikke Lærerne personlig, men mod hvad de repræsenterede, latent tilstede.

Denne reserverede eller fjendtlige Holdning hos Borgerskabet kom naturligvis til at indvirke paa Skolens Frekvens. Mange satte deres Børn i den slesvig-holstensk prægede Realskole, og nogle sendte dem til holstenske Latinskoler. Elevtallet, der i 1847 jo var 135, var i 1863 kun 95 . Hvad det betød, kan ses ved

24) En dansk og en tysk Læge ved Sindssygehospitalet. 
€n Sammenligning med Odense (der havde samme Indbyggerantal som Slesvig (godt 11.000). Katedralskolen her havde i 1847103 Elever, i 1863180 , var altsaa i 1847 betydelig mindre, men i 1863 dobbelt saa stor som Domskolen. Antallet af Studenter var i Slesvig gennemsnitlig 2 om Aaret, i Odense 7. Pueaktionen kunde ikke blive saa voldsom som i de mellemslesvigske Kirker, hvor Menigheden udeblev, naar der var dansk Gudstjenestę, thi alle de Hjem, der havde Ambitioner m. H. t. at lade deres Børm studere, var jo henvist til Domskolen. Men Reaktionen mærkes altsaa ogsaa her, de fleste Hjem, der har kunnet komme uden om den danskprægede lærde Skole, har undgaaet den.

Kritiken skød altsaa langt over Maalet. De danske Lærere var gennemgaaende dygtige og venlige Mennesker, nogle endog betydelige, og Gennemsnittet af dem paa ingen Maade ringere end ellers ved danske eller tyske Skoler.

Men i sit Udgangspunkt havde Kritiken Ret: Skolens Maai var - foruden det kundskabsmeddelende og karakteropdragende - at vække Følelser til Live i Drengen og Ungdommen, at de var Danske, den Følelse, man troede var latent tilstede. Danmark var Slesvigernes Fædreland, enten de talte Tysk eller Dansk, Danmarks Konge deres Konge, Dannebrog deres Flag, Danmarks Historie deres Historie, det blev sagt tit og ofte. Men det statsretslige Faktum, at Danmark gik til Ejderen, og dygtige Mænds Arbejde kunde ikke skabe Sejren; man havde valgt dernede. Og som altid - i hvert Fald før de sidste Aars stærke Statsindgreb i Hjemmene i visse Lande - : Naar Striden staar mellem Hjem og Skole, sejrer Hjemmet.

\section{Opløsning og Flugt}

I December 1863 og Januar 1864 var det svært at holde sammen paa Skolen - og sin egen Arbejdsvilje - saa meget skete der udenom og saa stærke og svingende var Stemningerne. 
Discipeltallet reduceredes stærkt, idet flere og flere af de tysksindede Forældre holdt deres Børn hjemme. I Slutningen af Januar maatte man slaa flere Klasser sammen. Drengene sad noget uroligt paa Bænkene.

2. Februar blev Skolebygningen rekvireret til Lazaret, ogsaa Rektors Embedsbolig vilde blive taget. ${ }^{25}$ ) Povelsen fik indrettet Klasser i Manicus' og Grünfelds Boliger (men dem blev der ikke Brug for).

3. Februar hjalp 4 i øverste Klasse Rektor med at bære hans Bøger op paa Biblioteket, da han hvert Øjeblik ventede Lazaretsengene.

Da Undervisningen begyndte om Morgenen - med knap Halvdelen af Eleverne - var det med den Aftale, at 3 Kanonskud skulde opløse Undervisningen for den Dag; Helms skulde bestemme, om man kunde kalde det „i Nærheden“. Snart lød der en Del Skud, men Sergeant Helms erklærede, at det næppe var skarpe Skud, og at man blot „blæste Kanonerne af“. Saa blev de, „og da vi netop i øverste Klasse (i Xenophon) havde om Sanseindtrykket og Forestillingen, behøvede vi ikke at lede efter et godt Eksempel" (3/2 1864).

Men der blev næppe læst meget. Skydningen blev ved, og da Formiddagen var gaaet, blev der givet Ferie, „foreløbig paa 3 Dage".

Det blev til mere end 3 Dage. Dansk Aand kom aldrig mere til at prøve sin Kraft i den gamle Skole ved Domkirkens Fod. Her paa de samme Steder havde Johannes Ewald gaaet og drømt sine Drømme om Bedrifter, dem Livet og Virkeligheden sønderslog. Paa lignende Maade drømte og haabede den unge danske Bevægelses Mand paa Fremgang og Sejr i de Egne, der før havde været danske. Men Befolkningen havde valgt og var tro i deres Tyskhed. Vi høstede kun Nederlag - og Erfaringer.

Den 5. Februar horte Helms (og de andre Lærere) Rygter om, at Dannevirke vilde blive forladt. Der var tomt paa Gaden, ingen

26) Rektors Embedsbolig var paa Skolen (der laa lige vest for Domkirken). Manicus' og Grünfeldts Embedsboliger laa lige i Nærheden. 
Soldater, ingen Civile; og stille inde i Stuen, man talte kun dæmpet sammen. ${ }^{26}$ )

Omtrent ved Midnat hørte man den tunge rullende Lyd af Kanoner paa Gaden, lidt dæmpet af den faldne Sne. Saa vidste man Besked.

Næste Morgen vaagnede han tidligt, vækket af „SchleswigHolstein meerumschlungen", og fra sit Vindue saa han Afdeling efter Afdeling af fjendtlige Tropper rykke ind i Byen.

Mellem 4 og 5 mødte en Blikkenslager og en Boghandler og meddelte ham, at han havde at være ude af Byen inden Kl. 6 „im Nahmen der Bürgerschaft", ellers kunde de ikke indestaa for hans "Leben und Gut".

Helms gik nu ind til Rektoren, men mødte paa Vejen Skolens Pedel, der gav ham en Seddel fra denne: der var ikke andet at gøre end at bøje sig for Nødvendigheden og rejse.

Han søgte nu ind til Blichert. Denne havde sammen med Rektoren og et Par andre faaet skaffet sig en Vogn. Der var ingen anden Udvej end se at komme sydpaa, først til Hamborg.

Det lykkedes ham at faa en Plads i Amtmandens Vogn.

Inden han tog hjemmefra vandede han sine Blomster, „det var mig næsten en Fornemmelse, som om jeg tog Afsked med levende Væsener“.

Jernbaneturen den næste Dag fra Rendsborg til Hamborg var ikke behagelig. Paa Mellemstationerne var der fulöt af Folk, og naar Toget holdt, styrtede de ind i det, for at faz "die Dänen“ at se, og der „blev kastet baade Skældsord og Snavs“ ind ad Vinduet til dem.

Paa Vejen senere i Toget fra Hamborg til Rostock traf han sin Kollega Jørgen Kruse (ansat 1862) med Kone og Barn, og Helms maatte paatage sig det Hverv ved Stationerne at stille Barnet op ved Vinduet; de vilde ikke gerne have Tyskerne ind.

Endelig kom de i Rostock ombord i et svensk Skib.

Om Aftenen samledes alle de fordrevne - et halvt Hundre-

2B, Helms: Nogle Erindringer fra de sidste Dage i Slesvig (Fortællinger ag Dige 1888. S. 5 ff). 
de Mennesker, mest unge eller yngre Mænd - om en Bolle Punsj. Mangt et Glas blev tømt paa, at de maatte vende tilbage under lykkeligere Omstændigheder, og ingen tvivlede paa, at det vilde ske.

Sent næste Nat kom de til Ystad. De lejede 7-8 Slæder, og afsted gik det i Mulm og Mørke til Malmø. Først den 11. Februar naaede de København, 6 Dages Rejse!

Som Helms' har vel ogsaa de andre Læreres Flugt været uhyggelig og spændende. Som han har de vel ogsaa troet paa, at de vilde vende tilbage under lykkeligere Omstændigheder. Det skete altsaa ikke.

Men indholdsrige og ejendommelige havde de været de Aar ved Slesvig Domskole. 